\title{
Republic of Latvia: Selected Issues
}

This selected Issues paper for the Republic of Latvia was prepared by a staff team of the International Monetary Fund as background documentation for the periodic consultation with the member country. It is based on the information available at the time it was completed on July 16, 2004. The views expressed in this document are those of the staff team and do not necessarily reflect the views of the government of the Republic of Latvia or the Executive Board of the IMF.

The policy of publication of staff reports and other documents by the IMF allows for the deletion of market-sensitive information.

To assist the IMF in evaluating the publication policy, reader comments are invited and may be sent by e-mail to publicationpolicy@imf.org.

Copies of this report are available to the public from

International Monetary Fund • Publication Services

$70019^{\text {th }}$ Street, N.W. • Washington, D.C. 20431

Telephone: (202) 623-7430 • Telefax: (202) 623-7201

E-mail: publications@imf.org Internet: http://www.imf.org

Price: $\$ 15.00$ a copy

\section{International Monetary Fund Washington, D.C.}





\title{
INTERNATIONAL MONETARY FUND
}

\author{
REPUBLIC OF LATVIA
}

\author{
Selected Issues \\ Prepared by Francesco Luna, Yuan Xiao (both EUR), \\ and Rupert DeLisle Worrell (MFD) \\ Approved by the European Department
}

July 16,2004

Contents

Page

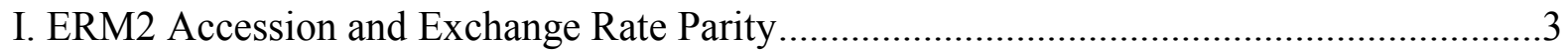

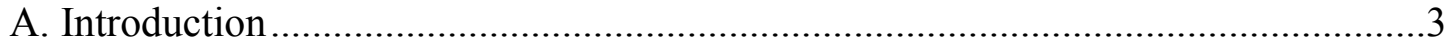

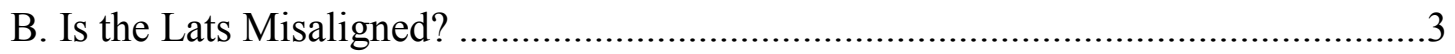

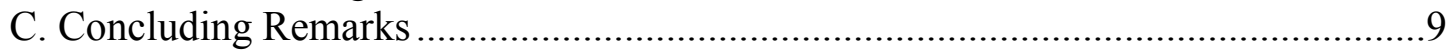

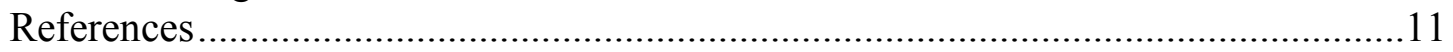

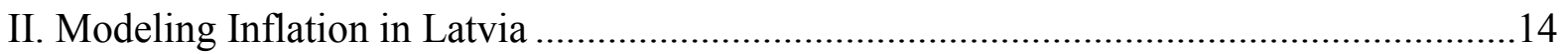

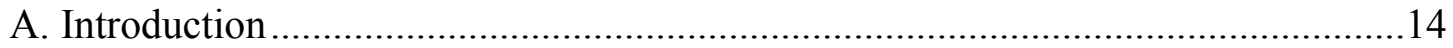

B. Error Correction -A Time Series Model..............................................................14

C. New Keynesian Open-Economy Phillips Curve-A Structural Equation ...............18

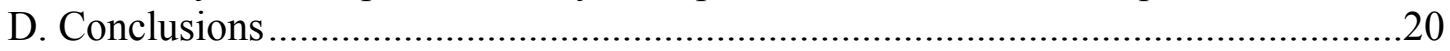

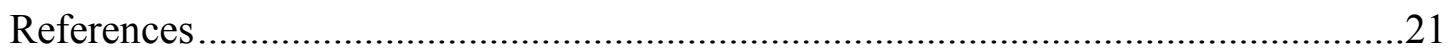

III. Financial Sector Strengths and Vulnerabilities - An Update ..........................................22

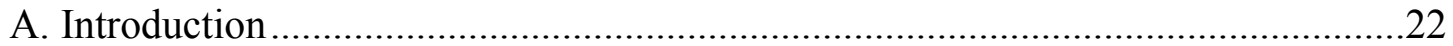

B. Recent Changes in the Financial Sector .............................................................22

C. Banking Stability Assessment..........................................................................23

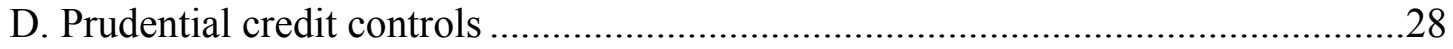

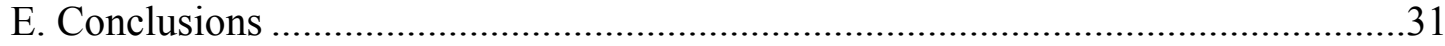

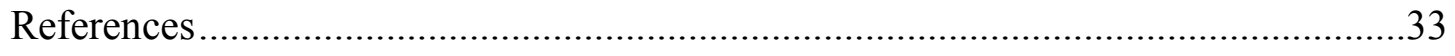

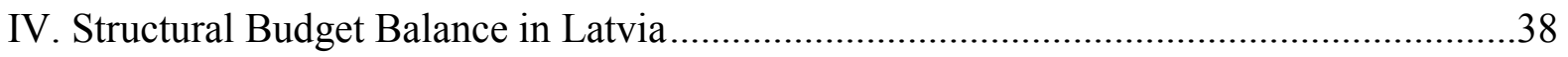

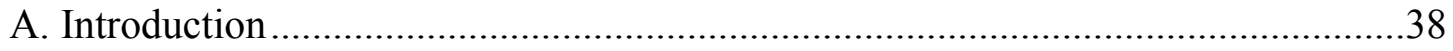

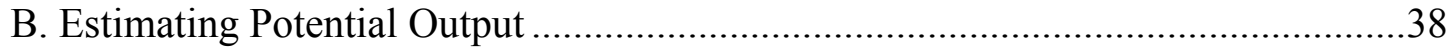

C. Calculating Structural Budget Balance ………………….....................................4

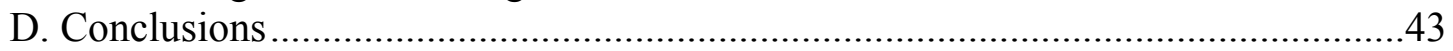

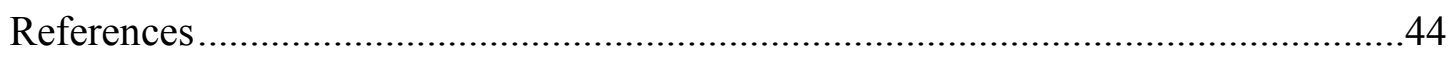




\section{Tables}

I.1. External Sustainability Framework, 1999-2008 ...........................................................12

I.2. Public Sector Debt Sustainability Framework, 1996-2008 .........................................13

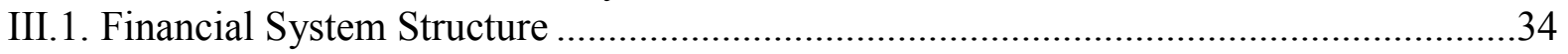

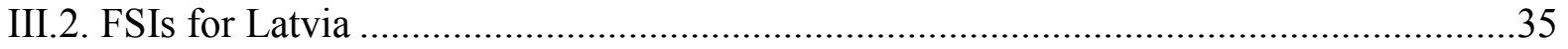

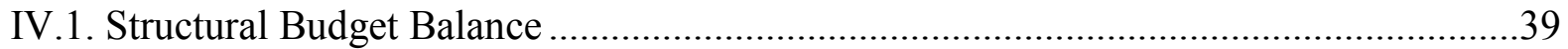

IV.2. Estimated Tax Elasticities............................................................................... 42

Figures

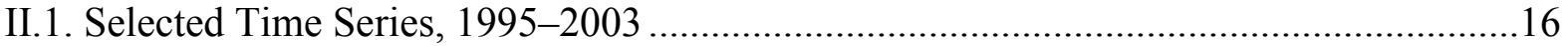

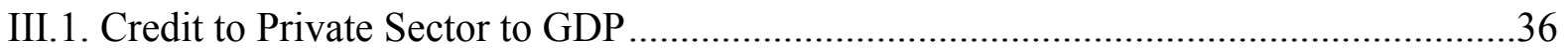

III.2. Apartment Price Comparisons - Countries............................................................... 36

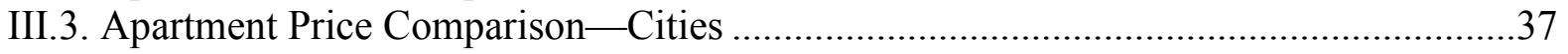

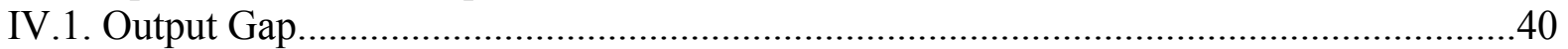

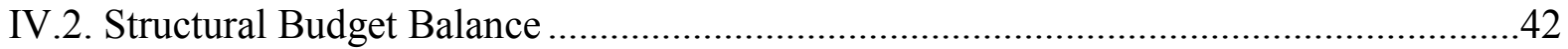




\section{ERM2 ACCession And EXchange Rate Parity ${ }^{1}$}

\section{A. Introduction}

1. The Latvian authorities plan to enter ERM2 in January 2005 and adopt the euro in January 2008 after the EU assessment, expected in mid-2007. This schedule, slower than the one proposed by the other two Baltic countries, seems justified by the need to abandon the current peg to the SDR and repeg to the euro. According to the plan, the new parity will be fixed at the market exchange rate prevailing on the day prior to ERM2 accession. The Bank of Latvia $(\mathrm{BoL})$ will unilaterally defend $\mathrm{a} \pm 1$ percent band around the parity-maintaining the regime currently in place.

2. In light of the large and widening external current account deficit, but also of the recent increase in inflation, this chapter attempts to assess whether the proposed strategy is appropriate. More specifically, it addresses the issue of a potential misalignment of the current parity. The findings do not support the hypothesis that the large current account deficit is due to an inherent exchange rate misalignment. However, since the entry to ERM2 and the repegging are scheduled for January 2005, a final assessment should be made toward the end of the year. While an open discussion of a possible realignment could trigger speculations in the foreign exchange market, the risks are more limited than in the other two Baltic countries because of the absence of a currency board or a fixed parity against the euro.

3. The chapter is organized in 3 Sections. Section B examines the possibility of an exchange rate misalignment from various perspectives. It considers different notions of the real effective exchange rate and competitiveness; deviations of the exchange rate from statistically-defined equilibrium concepts; the possibility that central bank foreign exchange interventions has maintained the exchange rate artificially away from equilibrium; export performance; and the sustainability of the current account under several scenarios. This Section finds little evidence of a major misalignment. Section $\mathrm{C}$ concludes by examining the risks caused by an inappropriate entry rate.

\section{B. Is the Lats Misaligned?}

\section{Previous studies}

4. In its "Strategy for the Accession to ERM2 and EMU," the BoL examines the issues of central parity and competitiveness, against the backdrop of the large external current account deficit, and concludes that the strategy should be appropriate as no obvious indication of misalignment exists. ${ }^{2}$ Burgess et al. $(2003)^{3}$ reach a similar conclusion

\footnotetext{
${ }^{1}$ Prepared by Francesco Luna.

${ }^{2}$ Bank of Latvia, 2004.

${ }^{3}$ Burgess, R., S. Fabrizio, and Y. Xiao (2003).
} 
examining various indicators of competitiveness for the three Baltic countries. As argued in IMF Country Report No. 03/331, structural factors such as an increase in expected income, productivity growth, and investments explain most of the deficit during the last decade. Most recently, Stavrev (2004) ${ }^{4}$ concludes that the observed large current account deficit in Estonia and Latvia can be broadly explained as rational consumption smoothing, even though the recent widening appears to be slightly above the level predicted by the intertemporal optimization model. Similarly, Bussière, Fratzscher and Müller (2004) $)^{5}$ estimate an expanded intertemporal model on a panel of 33 countries including the EU acceding countries and conclude that, from an intertemporal perspective, current accounts in the acceding countries are broadly in line with their structural current account positions.

\section{Exchange rate indicators}

5. Effective exchange rate indicators do not appear to suggest that Latvia suffers from a competitiveness problem. Indeed at end-2003, the Unit Labor Cost Real Effective Exchange Rate (REER), the CPI-based REER, and the PPI-based REER were all at or below early 1999 levels. The real depreciation started well before the US dollar depreciation with respect to the euro (see Chart), which translated in a similar trend in the SDR and, hence, of the lats. Lately, the competitiveness advantage deriving from this depreciation with respect to the euro area has been in part eroded by the higher inflation rate recorded in the last few months - 12-month CPI inflation at end-May 2004 was 6.2 percent. In any event, the correlation between the current account balance and the REER appears to be weak, pointing at other reasons for the imbalance.

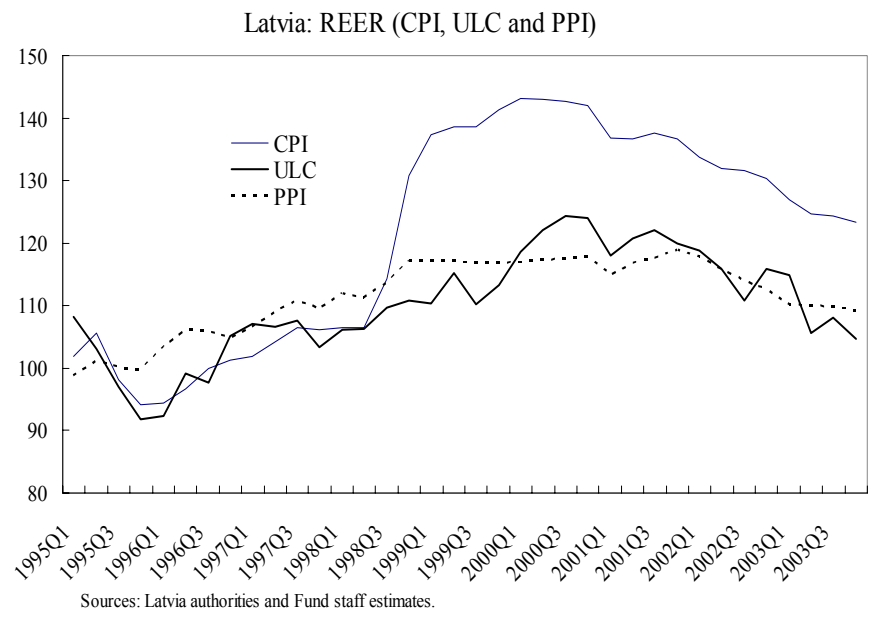

Current Account Balance and Real Effective Exchange Rate

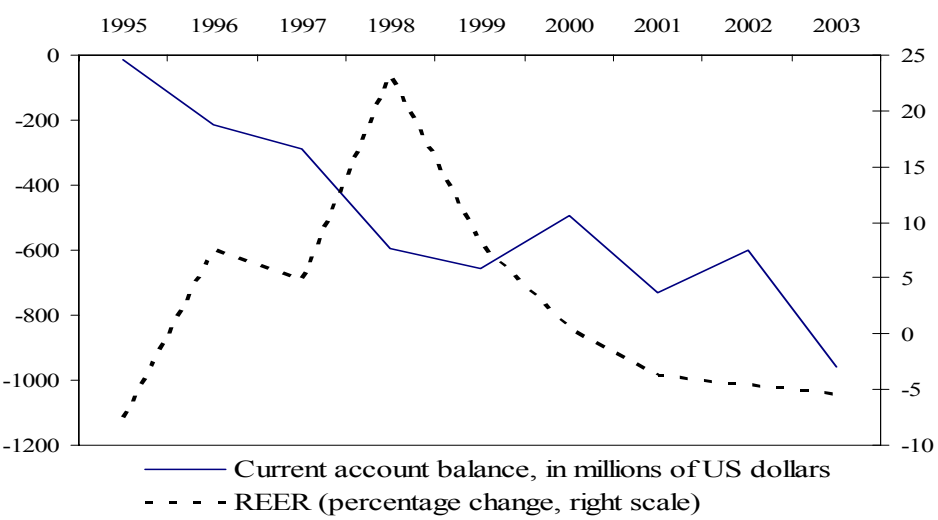

${ }^{4}$ Stavrev, Emil, (2004).

${ }^{5}$ Bussière M., M. Fratzscher and G. J. Müller (2004). 
6. Another indicator of a possible real exchange misalignment, the market-to-PPP exchange rate ratio, is on a slow, but continuous upward trend. This trend (with the ratio currently at 48 percent), however, seems to reflect the ongoing economic catching up more than a possible misalignment. Adjusted for per capita GDP, this ratio for Latvia is somewhat higher than for Estonia and about 10 percent lower than for Lithuania.

7. Current account deficits have been financed in large part by foreign direct investment and long term loans indicating the overall confidence of the international community in Latvia's development prospects. Such a confidence does not seem to have suffered when considering debt ratings and Latvia's competitiveness ranking. Moody assigns Latvia an A2 rating while Standard and Poor give an A- and Fitch an A. ${ }^{6}$

Approximated Yield Spreads Over German Government Bond (through May 12, 2004)

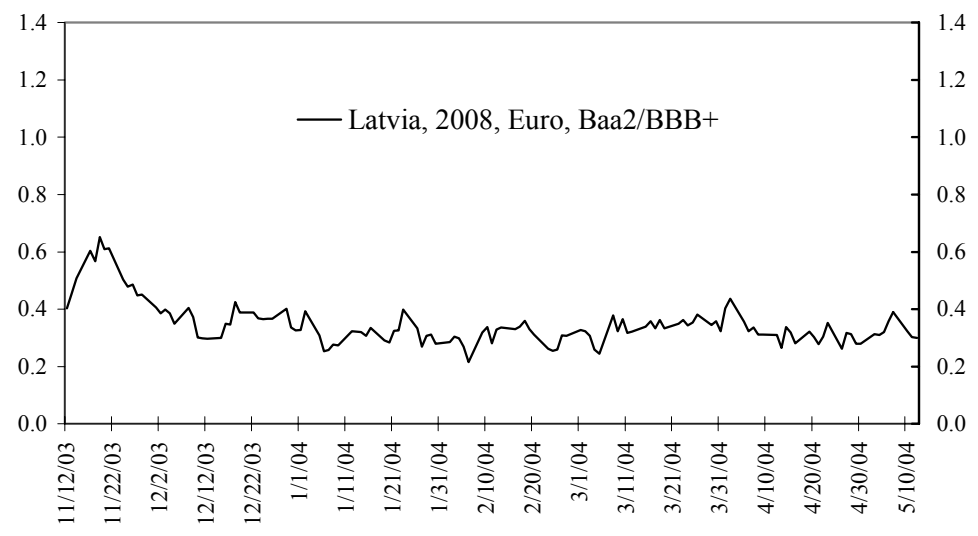

As for competitiveness, the overall Business Competitiveness Index (compiled in 2003 by the World Economic Forum) places Latvia just behind Estonia among the accession countries. Similarly, the spread on the Latvia Eurobond maturing in 2008-hovering between 30 and 40 basis points over the German benchmark - does not indicate any recent change in market perception.

\footnotetext{
${ }^{6}$ These are rating for long-term loans in local currency. Standard \& Poor assigns Latvia a credit rating of $\mathrm{BBB}+$ for long-term loans in foreign currencies, and $\mathrm{A}-2$ for all short-term loans.
} 


\section{Equilibrium exchange rate}

8. An alternative way to assess misalignment is to estimate the equilibrium exchange rate. In Burgess et al. (2003), the model estimation of the equilibrium REER for Latvia was found to be problematic because of time series high variability and no conclusion could be reached as to whether the exchange rate was under- or over-valued. A purely statistical approach (using an HP filter) seems to indicate that the equilibrium REER appreciated significantly until 1999 and that the process has slowed down afterwards and reversed in part. Given the shortcomings of this methodology — in particular, reliance only on information on the exchange rate and the end points problem - the results of this analysis are only indicative. They seem to suggest that during and immediately after the Russian

CPI- and PPI-Based Real Effective Exchange Rates and Corresponding HP-filtered Trends (Index, 1995=100)

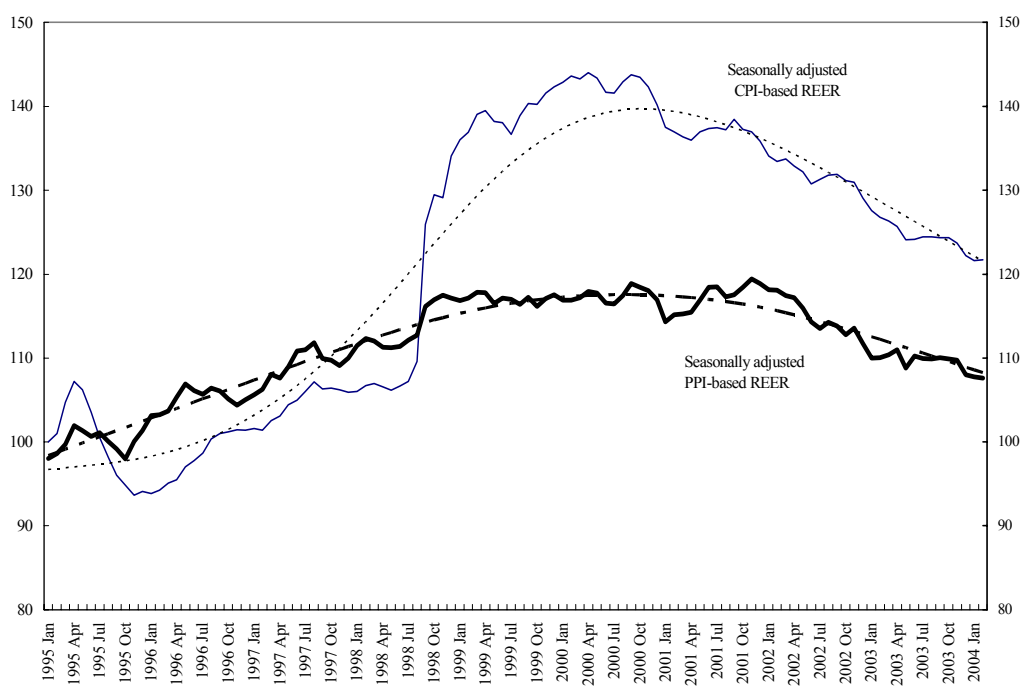
crisis, the CPI-based REER was overvalued, with a correction taking place at end-2000. Indeed, in 2000-02, wages grew less than productivity and only in 2003 did wage growth outpace productivity increases. This might be taken to indicate that currently the rate could be close to equilibrium.

9. Another indication that the exchange rate is not significantly away from equilibrium is the fact that the BoL's outright purchases of foreign exchange are rare and small. In the last 18 months, however, the BoL has been involved in continuous foreign currency swaps with commercial banks to provide them with needed liquidity. This could suggest that the parity is maintained artificially. To assess this possibility, a Granger causality test was performed on two subsamples of daily observations: June 2002-December 2003, and July 2003-December 2003. Even including foreign exchange swap operations, the "null hypothesis" that total interventions do not Granger cause the lats/SDR exchange rate cannot be rejected for all considered lag structures.

Estimation Results of Granger Causality Tests

\begin{tabular}{c|c|c|c|c}
\hline \multicolumn{3}{c|}{$\mathbf{6 / 0 2}-\mathbf{1 2 / 0 3}$} & \multicolumn{2}{c}{$\mathbf{7 / 0 3}-\mathbf{1 2 / 0 3}$} \\
\hline Lags & F-stat & Prob & F-stat & Prob \\
\hline 1 & 0.85 & 0.36 & 0.01 & 0.92 \\
\hline 2 & 0.71 & 0.49 & 0.73 & 0.47 \\
\hline 3 & 0.65 & 0.57 & 0.50 & 0.68 \\
\hline 4 & 0.77 & 0.54 & 0.55 & 0.69 \\
\hline 5 & 0.64 & 0.66 & 0.44 & 0.82 \\
\hline
\end{tabular}


This suggests that the parity is likely sustained by fundamentals and the potential ability of the BoL to intervene (with net international reserves equivalent to about 100 percent of reserve money) rather than by actual interventions.

\section{Export performance and profit margins}

10. An exchange rate overvaluation could also manifest itself in weak export performance. Latvia's export penetration, however, has proceeded steadily since 1999, despite unfavorable market situation for its main export, wood and wood products. Latvia's export market share in the world markets has surpassed the level reached before the Russian crisis in 1998. Market shares in EU and world markets have grown about 25 percent since 1999 and exports to the EU now accounts for about 65 percent of the

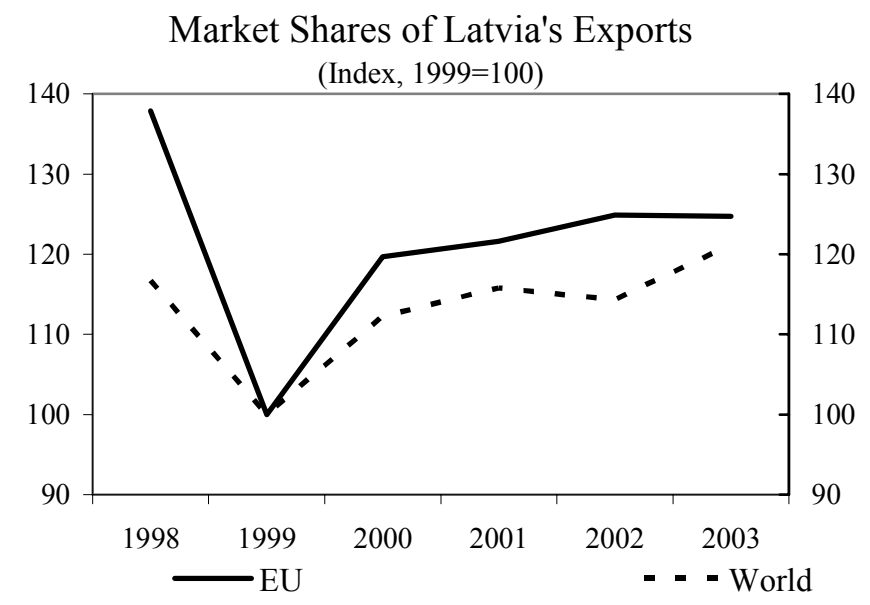
total (nearly 85 percent including the new accession countries).

Preliminary data for the first quarter of 2004 confirms a sustained export growth despite the persisting feeble activity levels in Latvia's European trading partners. Furthermore, export growth and the successful penetration of international markets have been accompanied by increasing profit margins over the last 5 years. Despite the limitations of the indicator employed - the ratio of wage $\operatorname{costs}^{7}$ to value added-for international comparisons, the figure Share of Wage Costs in Manufacturing Value Added, 1999-2003

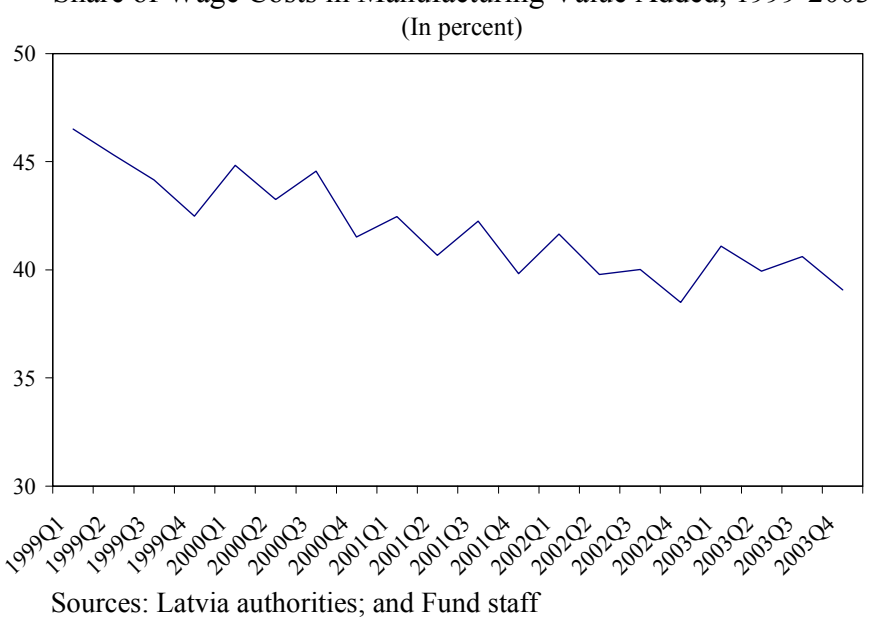
is at least indicative of a trend.

\footnotetext{
${ }^{7}$ For example, the ratio is certainly underestimated since it does not account for selfemployed workers in the sector for which no data are readily available.
} 


\section{Current account sustainability and the balance of payment}

11. Yet another indicator of a possible exchange rate misalignment is whether the current account is sustainable. According to the latest external debt sustainability analysis (see tables attached), there is no imminent risk. Gross international debt, at about 80 percent of GDP is largely due to the very high proportion of nonresident deposits, which are typically reinvested in liquid assets abroad closely matching the currencies of the deposits. For this reason, the notion of net external debt is more appropriate to assess Latvia's external vulnerability. Even in the most unfavorable scenarios considered, the situation should remain manageable, with net external debt remaining below 60 percent of GDP in most cases. Some other considerations, however, render the situation less rosy.

12. Foreign reserves in months of imports have recently declined to 2.2 and are expected to decrease further this year. However, this is due to the impressive imports growth rate driven by one-off capital purchases; in fact since independence, reserves have grown constantly in real terms.

13. In 2003, net FDI coverage of the CA deficit, at 34 percent, was well below the average observed in the last three years - nearly 60 percent. Since the rather comforting results of the external debt sustainability analysis were based on historical averages, a change in this trend could have significant repercussions and needs to be carefully monitored. Two factors weighed heavily on net FDI in 2003. First, due to a settlement between the government and Teliasonera (a Finnish company), Lattelekom capital was reduced and the part due to Teliasonera was recorded as negative FDI. Second, a significant part of loans extended by parent companies to Latvian enterprises matured in 2003 and was repaid rather than being rolled-over. The first factor is clearly one-off, while the interpretation of the second one is more problematic. It could indicate a change in attitude of parent companies that perceive their branches as mature enough to finance their activity independently. Else, it could be a cyclical phenomenon which may be reversed next year. In the first case, net FDI could remain lower for the next few years until these loans (assessed at 20 percent of the stock of FDI) are repaid. It is not clear what effect this could have on the maturity and currency composition of enterprise debt. In general, FDI are well distributed across economic sectors with prevalence in services (mainly trade and financial intermediation) and manufacturing, communication and transport accounting respectively for about 59 and 35 percent of the total.

14. From a "saving-investment balance" perspective, Latvia has a low savings rate (about 18.5 percent average between 1996 and 2003), not dissimilar to its Baltic neighbors, and one of the lowest among the accession countries. The overall trend is positive, but the larger current account deficit recorded in 2003 was accompanied by an equivalent decrease (about two percentage points) in private savings with a constant gross investment rate. Between 1996 and 2003, Latvia has grown on average 6 percent per annum, more than any other accession country. Even though it is not easy to make a direct connection between investment and growth, the evidence seems to indicate that the current account deficit is 
dictated by a successful catching up process, which should later result in an increased savings rate and lower current account deficits.

\section{Concluding Remarks}

15. Given the evidence collected, the exchange rate does not appear to be currently misaligned. However, by the end of the year circumstances may change and new elements could warrant the reassessment of this position. For example, the US dollar could appreciate significantly with respect to the euro, triggering a similar appreciation of the lats, or EU accession may have further impacts on inflation. In the event that a misalignment of the lats against the euro becomes apparent and large, and can be gauged with some precision, an entry rate different from that of the market could be considered. The assessment should weight the benefits of maintaining the parity implied by the market against the costs of possible overvaluation or undervaluation.

16. While ERM2 accession gives a good opportunity to correct any possible misalignment, a realignment of the parity away from the observed market rate, after it has held for 10 years, may generate a credibility crisis and confidence would have to be rebuilt. Furthermore, in case a depreciation of the lats is warranted, it will affect households who have US-dollar and euro-denominated mortgages. There are fortunately some mitigating factors. Recent stress tests performed in the context of an update of FSAP-related issues reveal that even a 30 percent increase in nonperforming mortgages would have only a minor impact on banks. And, in general, the limited open foreign exchange positions of banks would protect the system from even large depreciation of the lats against all currencies.

17. An overvalued parity could possibly worsen the current account deficit further, but as noted above the impact might be weak. In addition, prices in Latvia appear to respond quickly to nominal shocks and the labor market is rather flexible and could bear the blunt of the adjustment in the medium term, especially if the overvaluation is not excessive. Two more aspects should also be taken into consideration:

- $\quad$ EU accession may trigger the desire to emulate less flexible labor market contractual mechanisms from other European countries.

- $\quad$ As mentioned above, external debt is still moderate, but could accumulate more rapidly if nondebt creating FDI decrease. Furthermore, net foreign assets (at -50 percent of GDP) could be problematic.

18. An undervalued parity, on the other hand, could add to inflationary pressures and endanger meeting the Maastricht inflation criterion. While the recent increase in inflation is in large part due to one-off factors, the depreciation of the dollar against the euro has also played a part. Increased competitiveness through an undervalued entry rate would, therefore, be unlikely to last long. And, in any event, it could be ineffective in reducing the current account deficit owing to the weak correlation between the deficit and the exchange rate. 
19. In conclusion, while there is no reason to anticipate any major change in the circumstances between now and January 2005, the issue of the parity could be reassessed nearer the entry time. The benefits of the credibility gained by years of maintaining a fixed peg should be weighed against the costs associated with a possible misalignment. 


\section{References}

Bank of Latvia, 2004, Latvia's Strategy Towards ERM2 and the Adoption of the Euro. Background Material, mimeo.

Burgess, R., S. Fabrizio, and Y. Xiao, 2003, "Competitiveness in the Baltics in the Run-Up to EU Accession," IMF Country Report No. 114.

Bussière M., M. Fratzscher and G. J. Müller, February 2004, "Current Account Dynamics in OECD and EU Acceding Countries-An Intertemporal Approach,” ECB Working Paper Series No. 311.

Stavrev, Emil, March 2004, "Consumption-Smoothing, Productivity Shocks, and Current Account Balances in EU Accession Countries," IMF mimeo presented at the EUR seminar series. 
Table I.1. Latvia: External Sustainability Framework, 1999-2008 (In percent of GDP, unless otherwise indicated)

\begin{tabular}{|c|c|c|c|c|c|c|c|c|c|c|}
\hline & \multirow[b]{2}{*}{1999} & \multirow[b]{2}{*}{2000} & \multirow[b]{2}{*}{2001} & \multirow[b]{2}{*}{2002} & \multicolumn{6}{|c|}{ Projections } \\
\hline & & & & & 2003 & 2004 & 2005 & 2006 & 2007 & 2008 \\
\hline 1 External gross-debt & 52.9 & 61.0 & 67.7 & 75.7 & 82.6 & 82.8 & 87.9 & 91.7 & 95.6 & 98.3 \\
\hline External net-debt & 11.5 & 14.1 & 18.5 & 21.6 & 25.1 & 27.7 & 31.2 & 34.2 & 37.6 & 40.5 \\
\hline 2 Change in external gross debt & 2.0 & 8.1 & 6.7 & 8.0 & 6.8 & 0.2 & 5.1 & 3.9 & 3.8 & 2.7 \\
\hline 3 Identified external debt-creating flows $(4+8+11)$ & 1.3 & 0.4 & 2.6 & -2.2 & -8.6 & -6.8 & -2.0 & -3.1 & -3.6 & -4.0 \\
\hline 4 Current account deficit, excluding interest payments & 7.7 & 4.9 & 6.9 & 4.4 & 6.5 & 7.3 & 6.2 & 5.3 & 4.9 & 4.6 \\
\hline Deficit in balance of goods and services & 9.6 & 8.0 & 10.4 & 9.8 & 12.8 & 13.7 & 13.3 & 12.4 & 11.6 & 11.0 \\
\hline Exports & 40.3 & 42.3 & 41.4 & 41.6 & 42.4 & 42.2 & 44.5 & 46.2 & 47.8 & 49.3 \\
\hline Imports & 49.9 & 50.3 & 51.8 & 51.4 & 55.2 & 55.9 & 57.8 & 58.6 & 59.3 & 60.3 \\
\hline Net non-debt creating capital inflows (negative) 1 / & -3.6 & -2.1 & -2.7 & -2.7 & -3.6 & -3.8 & -3.6 & -3.5 & -3.3 & -3.2 \\
\hline Net foreign direct investment, equity & 2.5 & 2.7 & 2.6 & 2.7 & 1.8 & 2.1 & 1.9 & 1.8 & 1.6 & 1.5 \\
\hline Net portfolio investment,equity & 1.2 & -0.6 & 0.1 & 0.0 & 1.9 & 1.7 & 1.7 & 1.7 & 1.7 & 1.7 \\
\hline Automatic debt dynamics $2 /$ & -2.8 & -2.3 & -1.6 & -3.9 & -11.5 & -10.3 & -4.6 & -4.9 & -5.2 & -5.5 \\
\hline Contribution from nominal interest rate & 1.5 & 1.5 & 1.8 & 2.5 & 2.4 & 2.3 & 2.4 & 2.5 & 2.5 & 2.6 \\
\hline Contribution from real GDP growth & -1.3 & -3.4 & -4.6 & -3.7 & -4.6 & -4.5 & -4.5 & -4.8 & -5.0 & -5.3 \\
\hline Contribution from price and exchange rate changes 3 / & -3.0 & -0.5 & 1.2 & -2.7 & -9.3 & -8.1 & -2.4 & -2.6 & -2.7 & -2.8 \\
\hline 14 Residual, incl. change in gross foreign assets and exchange-rate valuation effects(2-3) 4/ & 0.8 & 7.7 & 4.1 & 10.2 & 15.4 & 7.0 & 7.1 & 7.0 & 7.4 & 6.8 \\
\hline Gross external debt-to-exports ratio (in percent) & 131.1 & 144.1 & 163.6 & 182.1 & 194.6 & 196.3 & 197.3 & 198.4 & 200.1 & 199.6 \\
\hline Net external debt-to-exports ratio (in percent) & 28.5 & 33.2 & 44.7 & 52.0 & 59.2 & 65.7 & 70.2 & 73.9 & 78.6 & 82.3 \\
\hline Gross external financing need (in billions of US dollars) 5/ & 3.5 & 3.9 & 4.8 & 5.4 & 6.7 & 8.1 & 9.0 & 10.1 & 11.3 & 12.4 \\
\hline in percent of GDP & 48.4 & 51.0 & 58.1 & 58.6 & 60.7 & 61.3 & 62.1 & 64.2 & 65.8 & 66.0 \\
\hline \multicolumn{11}{|l|}{ Key Macroeconomic and External Assumptions } \\
\hline Real GDP growth (in percent) & 2.8 & 6.8 & 7.9 & 6.1 & 7.4 & 6.5 & 6.0 & 6.0 & 6.0 & 6.0 \\
\hline Exchange rate appreciation (US dollar value of local currency, change in percent) & 0.8 & -3.5 & -3.5 & 1.6 & 8.3 & 7.7 & 0.0 & 0.0 & 0.0 & 0.0 \\
\hline GDP deflator in US dollars (change in percent) & 6.2 & 0.9 & -1.9 & 4.1 & 14.0 & 10.9 & 3.0 & 3.0 & 3.0 & 3.0 \\
\hline Nominal external interest rate (in percent) & 3.2 & 3.1 & 3.1 & 4.0 & 3.8 & 3.3 & 3.2 & 3.1 & 3.0 & 3.0 \\
\hline Growth of exports (GNFS in US dollar terms, in percent) & -8.2 & 12.3 & 4.1 & 12.5 & 22.7 & 18.6 & 15.3 & 13.4 & 12.8 & 12.6 \\
\hline Growth of imports (GNFS in US dollar terms, in percent) & -8.7 & 7.8 & 9.6 & 11.0 & 29.3 & 20.9 & 12.9 & 10.7 & 10.5 & 10.9 \\
\hline
\end{tabular}

1. GDP growth, interest rate, deflator, non-interest curr.acc., and non-debt inflows are at historical average in 2003-08

2. Nominal interest rate is at historical average plus 4 percentage points in 2004 and 2005

3. Real GDP growth is at historical average minus two standard deviations in 2004 and 2005

4. Change in US dollar GDP deflator is at historical average minus two standard deviations in 2004 and 2005

5. Non-interest current-account deficit is at historical average plus two standard deviations in 2004 and 2005

6. One time 15 percent nominal depreciation in 2004

7. FDI drops to 0.5 percent of GDP in 2004 and 2005 with 30 percent offsetting decline in imports
II. Stress Tests for External Gross Debt

$\begin{array}{rrrrrrr}75.7 & 82.6 & 88.7 & 95.1 & 101.1 & 107.3 & 112.5 \\ 75.7 & 82.6 & 85.7 & 93.8 & 97.3 & 100.9 & 103.3 \\ 75.7 & 82.6 & 86.3 & 94.7 & 98.3 & 101.7 & 104.2 \\ 75.7 & 82.6 & 95.1 & 106.8 & 109.6 & 112.5 & 114.3 \\ 75.7 & 82.6 & 84.9 & 92.8 & 96.4 & 100.0 & 102.5 \\ 75.7 & 82.6 & 102.5 & 106.5 & 109.3 & 112.2 & 114.0 \\ 75.7 & 81.0 & 83.5 & 87.2 & 90.2 & 92.3 & 94.5\end{array}$

III. Stress Tests for External Net Debt

$\begin{array}{lllllll}21.6 & 28.5 & 34.6 & 41.0 & 47.0 & 53.2 & 58.4 \\ 21.6 & 28.5 & 31.6 & 39.7 & 43.2 & 46.8 & 49.2 \\ 21.6 & 28.5 & 32.2 & 40.6 & 44.2 & 47.6 & 50.0 \\ 21.6 & 28.5 & 40.9 & 52.7 & 55.5 & 58.4 & 60.2 \\ 21.6 & 28.5 & 30.8 & 38.7 & 42.3 & 45.9 & 48.4 \\ 21.6 & 28.5 & 48.4 & 52.4 & 55.2 & 58.1 & 59.9 \\ 21.6 & 26.9 & 29.4 & 33.1 & 36.1 & 38.2 & 40.4\end{array}$

1. GDP growth, interest rate, deflator, non-interest curr. acc., and non-debt inflows are at historical average in 2003-08

2. Nominal interest rate is at historical average plus three percentage points in 2004 and 2005

3. Real GDP growth is at historical average minus two standard deviations in 2004 and 2005

4. Change in US dollar GDP deflator is at historical average minus two standard deviations in 2004 and 2005

5. Non-interest current account is at historical average minus two standard deviations in 2004 and 2005

6. One time 15 percent nominal depreciation in 2004

7. FDI drops to 0.5 percent of GDP in 2004 and 2005 with 30 percent offsetting decline in imports

Historical Statistics for Key Variables (past 3 years) 6/

\begin{tabular}{cc}
\hline $\begin{array}{c}\text { Historical Standard } \\
\text { Average Deviation }\end{array}$ \\
\hline 6.0 & 1.6 \\
2.8 & 0.6 \\
3.3 & 0.5 \\
5.9 & 2.2 \\
1.7 & 3.5
\end{tabular}

Current account deficit, excluding interest payments

Net non-debt creating capital inflows

Nominal interest rate (in percent)

Real GDP growth (in percent)

GDP deflator in US dollars (change in percent) 
Table I.2. Latvia: Public Sector Debt Sustainability Framework, 1996-2008 (In percent of GDP, unless otherwise indicated)

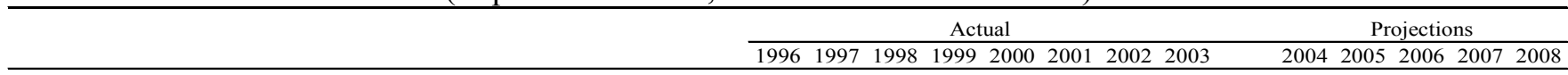

I. Baseline Medium-Term Projections

1 Public sector debt $1 /$

$\mathrm{o} / \mathrm{w}$ foreign-currency denominated

2 Change in public sector debt

3 Identified debt-creating flows $(4+7+12)$

4 Primary deficit

5 Revenue and grants

6 Primary (noninterest) expenditure

7 Automatic debt dynamics 2/

8 Contribution from interest rate/growth differential 3/

Of which contribution from real interest rate

Of which contribution from real GDP growth

Contribution from exchange rate depreciation 4/

12 Other identified debt-creating flows

Privatization receipts (negative)

Recognition of implicit or contingent liabilities

Other (specify, e.g. bank recapitalization)

16 Residual, including asset changes (2-3)

Public sector debt in percent of revenues 1/

Gross financing 5

in billions of U.S. dollars

Key Macroeconomic and Fiscal Assumptions

Real GDP growth (in percent)

Average nominal interest rate on public debt (in percent) 6/

Average real interest rate (nominal rate minus change in GDP deflator, in percent)

Nominal appreciation (increase in US dollar value of local currency, in percent)

Inflation rate (GDP deflator, in percent)

Growth of real primary spending (deflated by GDP deflator, in percent)

$\begin{array}{rrrrrrrr}13.3 & 11.0 & 9.6 & 12.1 & 12.2 & 13.8 & 13.3 & 13.4 \\ 7.7 & 6.1 & 5.9 & 8.6 & 7.4 & 8.8 & 8.2 & 10.2 \\ & & & & & & & \\ -1.3 & -2.3 & -1.3 & 2.4 & 0.1 & 1.6 & -0.5 & 0.1 \\ -0.5 & -3.0 & -1.6 & 2.6 & 1.8 & 0.6 & -0.3 & 0.9 \\ 0.4 & -1.1 & -0.2 & 2.8 & 2.2 & 1.2 & 1.7 & 1.8 \\ 34.4 & 37.9 & 39.2 & 36.9 & 34.6 & 32.8 & 33.0 & 32.0 \\ 34.8 & 36.8 & 38.9 & 39.8 & 36.9 & 34.1 & 34.6 & 33.8 \\ -0.8 & -0.5 & -0.3 & 0.2 & -0.1 & 0.0 & -1.1 & -1.2 \\ -1.1 & -0.9 & 0.0 & 0.0 & -0.4 & -0.4 & -0.5 & -0.3 \\ -0.7 & 0.0 & 0.5 & 0.3 & 0.3 & 0.5 & 0.3 & 0.6 \\ -0.5 & -0.9 & -0.5 & -0.3 & -0.8 & -0.9 & -0.8 & -0.9 \\ 0.3 & 0.4 & -0.2 & 0.2 & 0.4 & 0.3 & -0.6 & -0.9 \\ -0.1 & -1.3 & -1.1 & -0.5 & -0.3 & -0.6 & -0.9 & 0.3 \\ -0.1 & -1.3 & -1.1 & -0.5 & -0.3 & -0.6 & -0.9 & -0.2 \\ 0.0 & 0.0 & 0.0 & 0.0 & 0.0 & 0.0 & 0.0 & 0.5 \\ 0.0 & 0.0 & 0.0 & 0.0 & 0.0 & 0.0 & 0.0 & 0.0 \\ -0.8 & 0.7 & 0.3 & -0.1 & -1.7 & 1.0 & -0.2 & -0.8 \\ & & & & & & & \\ 38.6 & 29.0 & 24.6 & 32.7 & 35.2 & 42.0 & 40.3 & 41.8 \\ & & & & & & & \\ 5.9 & 5.8 & 4.5 & 6.4 & 6.5 & 4.3 & 3.6 & 5.0 \\ 0.3 & 0.4 & 0.3 & 0.5 & 0.5 & 0.4 & 0.3 & 0.6\end{array}$

$\begin{array}{lllll}15.1 & 15.4 & 15.6 & 15.8 & 16.0\end{array}$ $\begin{array}{lllll}11.7 & 12.4 & 12.7 & 12.7 & 12.5\end{array}$

$\begin{array}{lllll}1.7 & 0.3 & 0.2 & 0.2 & 0.2\end{array}$ $\begin{array}{lllll}1.3 & 0.7 & 0.3 & 0.1 & -0.2\end{array}$ $\begin{array}{lllll}1.6 & 0.7 & 0.5 & 0.3 & 0.0\end{array}$ $\begin{array}{lllll}28.9 & 34.6 & 34.8 & 34.9 & 35.1\end{array}$ $\begin{array}{llllll}30.5 & 35.4 & 35.3 & 35.2 & 35.1\end{array}$ $\begin{array}{lllll}-0.6 & -0.4 & -0.4 & -0.5 & -0.5\end{array}$ $\begin{array}{lllll}-0.3 & -0.4 & -0.4 & -0.5 & -0.5\end{array}$ $\begin{array}{lllll}0.4 & 0.5 & 0.4 & 0.4 & 0.4\end{array}$ $\begin{array}{lllll}-0.8 & -0.8 & -0.8 & -0.9 & -0.9\end{array}$ $\begin{array}{lllll}-0.2 & 0.0 & 0.0 & 0.0 & 0.0\end{array}$ $\begin{array}{lllll}0.3 & 0.3 & 0.3 & 0.3 & 0.3\end{array}$ $-0.1 \quad-0.1 \quad-0.1 \quad-0.1 \quad-0.1$ $\begin{array}{lllll}0.4 & 0.4 & 0.4 & 0.4 & 0.4\end{array}$ $\begin{array}{lllll}0.0 & 0.0 & 0.0 & 0.0 & 0.0\end{array}$ $\begin{array}{llllll}0.4 & -0.4 & -0.1 & 0.1 & 0.3\end{array}$

$\begin{array}{lllll}52.3 & 44.6 & 44.9 & 45.3 & 45.6\end{array}$

$\begin{array}{lllll}5.4 & 3.2 & 3.0 & 2.2 & 1.9\end{array}$ $\begin{array}{llllll}0.7 & 0.5 & 0.5 & 0.4 & 0.4\end{array}$

$\begin{array}{rrrrr}6.5 & 6.0 & 6.0 & 6.0 & 6.0 \\ 7.9 & 6.6 & 6.1 & 5.8 & 6.0 \\ 3.9 & 3.6 & 3.1 & 2.8 & 3.0 \\ 2.1 & 0.0 & 0.0 & 0.0 & 0.0 \\ 4.0 & 3.0 & 3.0 & 3.0 & 3.0 \\ -3.8 & 22.9 & 5.8 & 5.7 & 5.7\end{array}$

\section{Stress Tests}
1. Real GDP growth, real interest rate, and primary balance are at historical averages in 2004-08
2. Real interest rate is at historical average plus two standard deviations in 2004 and 2005
3. Real GDP growth is at historical average minus two standard deviations in 2004 and 2005
4. Primary balance is at historical average minus two standard deviations in 2004 and 2005
5. Combination of 2-4 using one standard deviation shocks
6. One time 30 percent real depreciation in $20047 /$
7. 10 percent of GDP increase in other debt-creating flows in 2004
8a. Impact on debt-to-revenue ratio if revenue-to-GDP ratio is at historical average minus two standard deviations in $2004-05 \quad 41.8$
Historical Statistics for Key Variables (1996-2003)
Primary deficit
Real GDP growth (in percent)
Nominal interest rate (in percent) 6/
Real interest rate (in percent)
Inflation rate (GDP deflator, in percent)
Revenue to GDP ratio

\begin{tabular}{|c|c|}
\hline $\begin{array}{l}\text { Historical } \\
\text { Average }\end{array}$ & $\begin{array}{l}\text { Standard } \\
\text { Deviation }\end{array}$ \\
\hline 1.1 & 1.3 \\
\hline 6.1 & 1.9 \\
\hline 8.1 & 1.4 \\
\hline 2.6 & 3.4 \\
\hline 5.5 & 4.0 \\
\hline 35.1 & 2.6 \\
\hline
\end{tabular}

1/ Indicate coverage of public sector, e.g., general government or nonfinancial public sector. Also whether net or gross debt is used.

2/ Derived as $[(\mathrm{r}-\pi(1+\mathrm{g})-\mathrm{g}+\alpha \varepsilon(1+\mathrm{r})] /(1+\mathrm{g}+\pi+\mathrm{g} \pi))$ times previous period debt ratio, with $\mathrm{r}=$ interest rate; $\pi=$ growth rate of GDP deflator; $\mathrm{g}=$ real GDP growth rate; $\mathrm{a}=$ share of foreign-currency denominated debt; and $\mathrm{e}=$ nominal exchange rate depreciation (measured by increase in local currency value of U.S. dollar).

3 / The real interest rate contribution is derived from the denominator in footnote $2 /$ as $r-\pi(1+\mathrm{g})$ and the real growth contribution as $-\mathrm{g}$.

4 / The exchange rate contribution is derived from the denominator in footnote $2 /$ as $\alpha \varepsilon(1+r)$.

5/ Defined as public sector deficit, plus amortization of medium and long-term public sector debt, plus short-term debt at end of previous period.

6/ Derived as nominal interest expenditure divided by previous period debt stock.

7/ Real depreciation is defined as nominal depreciation (measured by percentage fall in dollar value of local currency) minus domestic inflation (based on GDP deflator). 


\section{Modeling Inflation In LAtVia ${ }^{1}$}

\section{A. Introduction}

1. After plagued by double digit inflation in the early stage of the transition, Latvia achieved inflation stability by the end-1990s, with an annual average inflation rate generally below 3 percent since then. The introduction of the exchange rate peg with respect to the SDR in 1994, together with a prudent macroeconomic policy mix, has helped maintain the low inflation environment. This, in turn, has enabled FDI and domestic business to thrive, thus contributing to sustained economic growth. Although inflation has accelerated recently, reaching about 6 percent by mid-2004, the increase is largely due to one-off factors, such as those associated with the EU accession.

2. This chapter aims to assess the quantitative relationship between inflation and its determinants in Latvia. On the supply side, labor costs and input costs, such as the price of oil, are factors determining the prices of domestically produced goods. On the demand side, the output gap is likely to play a role. In addition, domestic credit has been expanding rapidly in the last few years, at an annual rate of more than 30 percent. The extra liquidity may have contributed to rising prices. On the other hand, Latvia is a small and highly open economy, which implies that, apart from domestic factors, its price level is also affected by world prices and the exchange rate. What is the relative importance of these factors in Latvia? We address this question quantitatively in two frameworks. We first take the time series approach and build an error correction model of inflation. The objective is to link the short run dynamics to a long run equilibrium relationship which determines the price level. We then attempt to estimate a New Keynesian open economy Phillips curve, which has the merit of capturing the rational, forward-looking price setting behaviors of the economy agents, and the estimated parameters of which have structural interpretations.

\section{B. Error Correction-A Time Series Model}

3. In order to disentangle the dynamics of inflation and its determinants, we construct an error correction model, combining the short run adjustments of inflation and the long run equilibrium relationship for the price level. Shocks to the economy could cause the price level to deviate from its long run equilibrium path, but inflation in the subsequent periods will adjust to close the gap.

4. To examine the long run determinants of the price level, it is useful to divide the CPI basket into two components: nontraded goods whose prices are determined by production costs in the domestic market, and tradable goods whose prices are largely determine by world

\footnotetext{
${ }^{1}$ Prepared by Yuan Xiao.
} 
prices. Denoting the $\mathrm{CPI}^{2}$ by $p$, it can be expressed as the weighted average of the price indices of its nontraded component $\left(p^{D}\right)$ and tradable component $\left(p^{T}\right)$ :

$$
p_{t}=(1-\omega) p^{D}{ }_{t}+\omega \cdot p^{T}{ }_{t}, 0<\omega<1 .
$$

5. We assume that domestic prices depend on the nominal unit labor cost, oil prices, and domestic credit: $p_{t}^{D}=\mu_{1} n u l c_{t}+\mu_{2} p_{t}{ }^{\text {OIL }}+\mu_{3}$ credit $_{t}$ (the output gap is not included since it is a short run factor). Assuming further that the price index of imported goods is a function of the foreign price index expressed in lats: $p_{t}^{M}=k\left(p_{t}^{W}+s_{t}\right)$, where $0<k \leq 1$ measures the degree of exchange rate and foreign price pass-though to import prices, and $s_{t}$ is the exchange rate, defined as the price of one unit of foreign currency in terms of lats. Combining these two relationships, we have

$$
p_{t}=(1-\omega)\left(\mu_{1} n u l c_{t}+\mu_{2} p_{t}^{\text {OIL }}+\mu_{3} \text { credit }_{t}\right)+\omega k\left(p^{W}{ }_{t}+s_{t}\right) .
$$

Eq. (2) depicts the comovement of the price level, the unit labor cost, the oil price, domestic credit, and the exchange-rate-adjusted foreign price, and can be regarded as a relationship that holds in equilibrium.

6. We use the Granger two-step procedure to estimate the error correction model. First, we estimate Eq. (2) by OLS using quarterly data for the period 1995:Q1 to 2003:Q4. We use the nominal effective exchange rate and calculate the foreign price index by the corresponding country weights. We find the following equilibrium relationship: ${ }^{3}$

$$
p=0.37\left(p^{W}+s\right)+0.38 \text { nulc }+0.04 \text { credit }+0.01 p^{\mathrm{OIL}}+E C .
$$

\footnotetext{
${ }^{2}$ In what follows, the levels of all variables are expressed in logarithms.

${ }^{3}$ As a preliminary step, We conduct augmented Dicky-Fuller (ADF) unit root tests on the variables, and find all are I(1) except for CPI and domestic credit, which appear to be I(0) and $\mathrm{I}(2)$. On the other hand, the ADF test does indicate that the residual in Eq. (3) is stationary, which seems to suggest the absence of an I(2) variable in the equation. Noting the very low power of these unit root tests given the short sample period, we proceed nonetheless.
} 
Figure II.1. Selected Time Series, ${ }^{1}$ 1995-2003
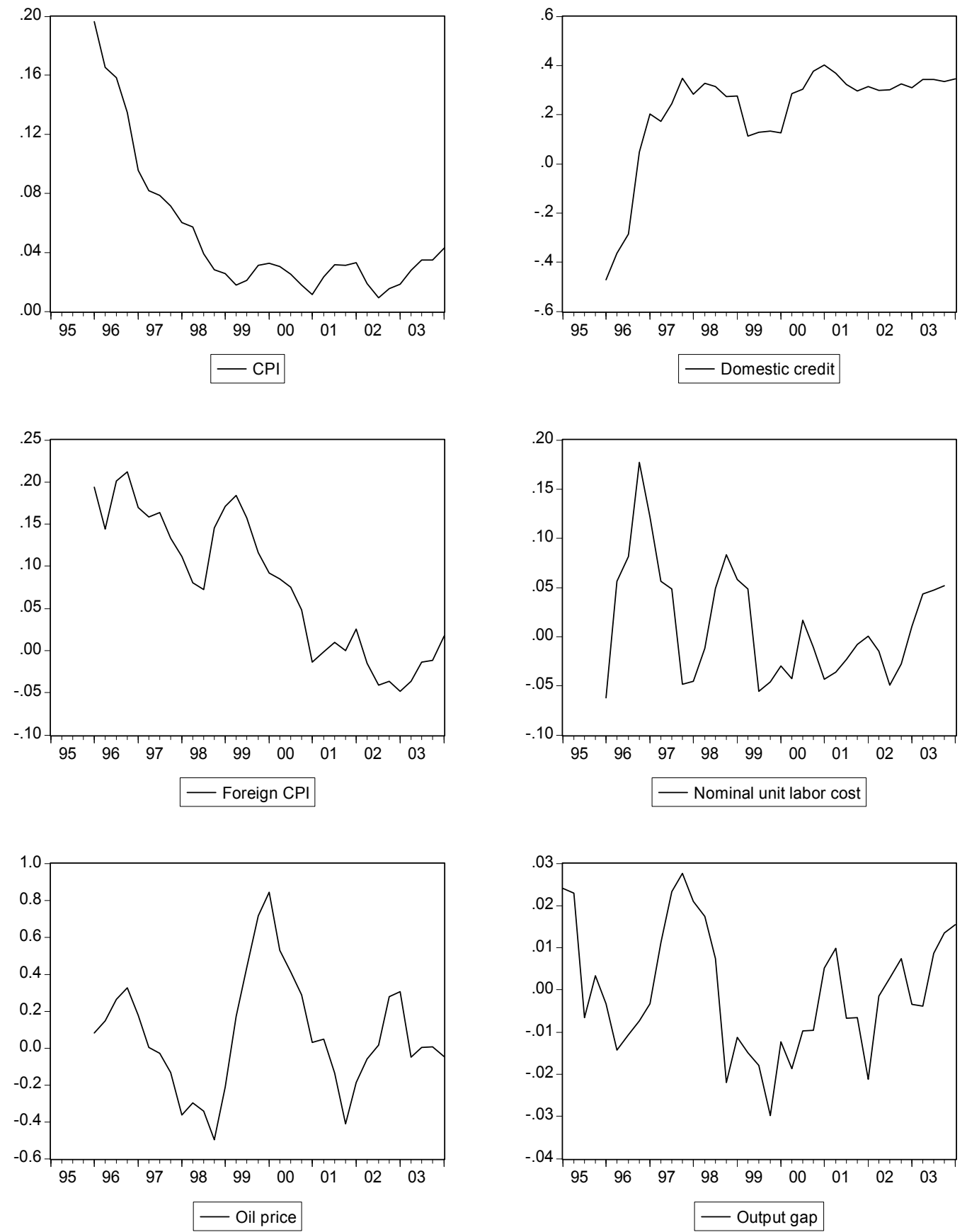

${ }^{1}$ Four-quarter percent changes except the output gap. 
7. All the estimated coefficients have correct signs and plausible sizes, and the residual $E C$ appears to be stationary according to the ADF test. Foreign prices and the unit labor costs appear to be the dominant factors, and both have comparable influences on CPI. The oil price term has a very small coefficient. This could be explained by the high volatility of the oil price series (see Figure II.1).

8. Domestic credit displays a positively correlation with the price level, but with a small elasticity of 0.04 . The absence of significant comovement between domestic credit and the price level during the sample period can be seen in Figure II.1. The domestic credit series is characterized by the credit contraction during the 1996 financial crisis in Latvia, the slow expansion during the Russia crisis, and the rapid growth period since then. However, there were no obvious associated changes in the price level. Overall, inflation was high in the beginning of the sample, while credit declined, and inflation dropped to a low level since 1999, while credit growth soared. Therefore it is not surprising that during the sample period price and credit display a weak correlation. In addition, rapid credit expansion in recent years appears to be endogenously driven by the catching up process towards the equilibrium credit to GDP ratio.

9. The error correction framework postulates that if the price level deviates from the equilibrium represented in Eq. (3), inflation will adjust to close the gap indicated by the $E C$ term. Such adjustments are described in a short run inflation equation. The econometric work yields the following result for the short run dynamics:

$$
\begin{aligned}
& \Delta p_{t}=0.65 * * \Delta p_{t-1}-0.12 * *\left(\Delta p_{t-1}^{W}+\Delta s_{t-1}\right)+0.39 * * y_{t-1}^{G A P}+0.20 * y_{t-2}^{G A P} \\
& \text { (0.12) (0.04) (0.09) (0.10) } \\
& +0.08 * * \text { nulc }_{t-1}+0.13^{* *} \Delta \text { nulc }_{t-2}+0.15^{* *} \Delta n u l c_{t-3}+0.03 * * \Delta p^{\text {OIL }}{ }_{t-1} \\
& (0.03) \\
& (0.02) \\
& +0.02 * * \Delta p_{t-2}^{O I L}+0.03 * * \Delta p^{O I L}{ }_{t-3}-0.03 * * \Delta p_{t-4}-0.17 * * E C_{t-1}+\varepsilon_{t} \text {. } \\
& (0.01)
\end{aligned}
$$

Notes: $\Delta$ denotes one-quarter percent changes. Standard errors are in parentheses. $* *$ denotes significance at 5 percent level. $*$ denotes significance at 10 percent level. $\mathrm{R}^{2}=0.93$. Durbin-Watson statistic $=2.04$.

10. Eq. (4) shows that inflation depends on its own lag, foreign inflation and the change of the exchange rate, the output gap, the change in the unit labor cost, the change in oil prices, and the measure of disequilibrium in the previous period. ${ }^{4}$ The output gap is defined as the percentage deviation of seasonally adjusted GDP from its trend constructed by the HP filter. The price of oil is measured in lats. The estimated coefficients have correct signs and

\footnotetext{
${ }^{4}$ The estimated coefficients could vary quite a bit if certain variables in Eq. (4) are omitted. This lack of robustness is likely due to the short length of the data.
} 
have plausible magnitudes. Inflation would rise if the nominal unit labor cost rises or if there is a positive output gap. Oil price inflation has overall a positive but small contribution to inflation. Inflation also displays strong serial correlation. Credit growth does not enter the equation significantly.

11. The coefficient on the error correction term indicates that the inflation rate would fall by 0.17 percentage points in the quarter for a price level that is one percent higher-thanequilibrium in the previous period. The data reveals a negative coefficient on the foreign inflation / exchange rate change term, generating some complex dynamics in response to a foreign price / exchange rate shock. For example, suppose a one time depreciation of 10 percent occurred in period $t$. This would cause a disequilibrium in the long run price equation, and according to Eq. (3), the price level has to rise by 3.7 percent to close the gap. ${ }^{5}$ The $E C$ term suggests that inflation in period $t+1$ will rise by $0.17 \times 3.7$ percentage points, but the negative coefficient on the foreign inflation term causes inflation to fall by $0.12 \times 10$ percent. The net effect is a decline in inflation period $t+1$, and only in subsequent periods does inflation start to rise. This results in a hump-shaped adjustment of inflation to an exchange rate shock which calls for further investigation.

\section{New Keynesian Open-Economy Phillips Curve-A Structural Equation}

12. We next explore the relationship between inflation, the domestic demand factor, and the exchange rate and in a forward-looking open-economy Phillips curve. While the intuition is similar to Eq. (2), i.e., CPI is determined by its two components: the nontraded goods whose prices are determined by production costs in the domestic market, and tradable goods whose prices are largely determine by the world prices, it incorporates the rational, forwardlooking price-setting behavior of agents. Since it is derived from models of optimizing agents and nominal rigidity, the parameters have structural interpretations.

13. The closed economy New Keynesian Phillips curve is a result from optimizing representative agent models with monopolistic competition and sluggish price adjustments, such as in the Calvo (1983) type (see e.g., Roberts, 1995, Gali and Gertler, 1999, Walsh, 2003):

$$
\Delta p_{t}^{D}=\beta E_{t} \Delta p_{t+1}^{D}+\alpha \cdot r u l c_{t}+v_{t}
$$

Here nontaxable inflation is linked with expected future inflation, and the real unit labor cost serves a measure of domestic demand pressure. From Eq. (1), we have

\footnotetext{
${ }^{5}$ This example is an oversimplification, as the responses of the other variables in the system also need to be considered. However, this would require estimating the full system which is not feasible given the short data series.
} 
$\Delta p_{t}=(1-\omega) \Delta p^{D}{ }_{t}+\omega \Delta p^{T}{ }_{t}$. Substituting (5) for $\Delta p^{D}{ }_{t}$ and utilizing $\Delta p_{t}^{T}=k\left(\Delta p_{t}^{W}+\Delta s_{t}\right)$ will yield the so-called New Keynesian open-economy Phillips curve:

$$
\Delta p_{t}=\beta E_{t} \Delta p_{t+1}+\alpha \cdot r u l c_{t}+k \omega\left(\Delta q_{t}-\beta E_{t} \Delta q_{t+1}\right)+u_{t},
$$

where $q$ is the real exchange rate. Eq. (6) augments the closed-economy Phillips curve by the real depreciation and the expected real depreciation. Here the parameters have structural interpretations. $\beta$ represents the discount factor, $\omega$ reflects the share of tradables in the CPI, and $k$ measures the degree of foreign price / exchange rate pass-through to import prices.

14. Since Eq. (6) includes expectation terms which are not observable, the Generalized Method of Moments is required for estimation. The expected values in Eq. (6) will be replaced by their actual future values and forecast errors are included in the error term. The resulting equation can then be estimated using instrumental variables. ${ }^{6}$ We estimate Eq. (6) using quarterly seasonally adjusted data. The results are as follows:

$$
\begin{aligned}
& \Delta p_{t}=0.24 * *+0.69 * * \mathrm{E}_{t} \Delta p_{t+1}+0.04 * * \text { rulc }_{t}+0.20 * *\left(\Delta q_{t}-0.69 * * \mathrm{E}_{t} \Delta q_{t+1}\right) \\
& \begin{array}{llll}
(0.03) & (0.05) & (0.00) & (0.04)
\end{array} \\
& -0.01 * * p_{t}^{O I L}+\varepsilon_{\mathrm{t}} \\
& \text { (0.00) }
\end{aligned}
$$

Notes: Standard errors are in parentheses. $* *$ denotes significance at 5 percent level. $\mathrm{R}^{2}=0.26$. Durbin-Watson statistic $=1.44$.

15. All the coefficients have the right signs and plausible magnitudes, except for the oil price term. However, its size is insignificant. The discount factor is 0.69 . The elasticity on the real unit labor cost is 0.04 , which suggests that the link between inflation and the domestic demand factor is modest. This is different from the error correction model, where inflation responds strongly to the output gap. However, as the output gap also indicates future inflation and the error correction model is a reduced form specification, the coefficients there could have captured the forward-looking characteristic of the inflation process. The elasticity on the real exchange rate is 0.20 . Recall that, from the model, it measures the share of tradable goods in CPI, modified by the degree of price pass-through to imported goods. Other things being equal, a 10 percent real depreciation is associated with a 2 percent high inflation.

\footnotetext{
${ }^{6}$ The instruments include a constant and four lags of each of the following: quarterly inflation, the real unit labor cost, the change in the real exchange rate, and the change in the price of oil.
} 


\section{Conclusions}

16. In this chapter we have attempted to model inflation in Latvia via two approaches: an error correction model and a forward-looking Phillips curve. We find that foreign prices, the exchange rate, and the unit labor cost are important determinants of the price level in the long run, while oil prices have limited influences. We also demonstrate the absence of significant comovement between inflation and credit growth in the past decade. In the short run, inflation in each quarter tends to close 17 percent of the gap created by the disequilibrium in the previous period. The output gap and the change in the unit labor costs also play important roles in the short run dynamics. A New Keynesian Phillips curve is also estimated, which shows that inflation is forward-looking, and responds significantly to a depreciation of the exchange rate.

17. It should be noted that the results presented in this chapter are only tentative. The sample period is too short to test the stability of the models, and it may require a longer period for certain key relations in the economy to unravel. Therefore a significant degree of uncertainty remains about the estimated parameters in the models, and future studies are called for to improve the reliability of the results. Nevertheless, the fact that these initial results seem to conform to the predictions of standard economic theories is promising. 


\section{References}

Calvo, Gullermo A.,1983, "Staggered Prices in a Utility-Maximizing Framework," Journal of Monetary Economics, Vol. 12(3), 383-398.

Gali, Jordi, and Mark Gertler, 1999, "Inflation Dynamics: A Structural Econometric Analysis,” Journal of Monetary Economics, Vol. 44(2), 195-222.

Kara, Amit, and Edward Nelson, 2004, "The Exchange Rate and Inflation in the U.K.," CEPR Discussion Papers No. 3783.

Roberts, John M.,1995, "New Keynesian Economics and the Phillips Curve," Journal of Money, Credit, and Banking, Vol. 27(4), 975-984.

Walsh, Carl E., 2003, Monetary Theory and Policy, $2^{\text {nd }}$ Edition, Cambridge, The MIT Press. 


\section{FinanCial Sector Strengths AND Vulnerabilities-An UPDATE ${ }^{1}$}

\section{A. Introduction}

1. This chapter reports on strengths and vulnerabilities that may have developed in the financial system since the time of the Latvia Financial System Stability Assessment (IMF Country Report No. 02/67), and discusses measures available to the authorities for further strengthening of the system. The FSSA found that the banking system was well capitalized, profitable and liquid. It was "fairly resilient" to interest rate increases, rapid credit expansion and possible withdrawal of nonresident deposits. The FSSA recommended continued vigilance by banks and the Financial and Capital Markets Commission (FCMC) to ensure that new vulnerabilities did not develop in these areas. Nonbank financial institutions were judged not large enough to be a source of systemic risk. Supervision and regulation were judged to be robust.

2. The present assessment is based mainly on an analysis of financial soundness indicators, including macroeconomic indicators such as inflation, and on stress tests of the financial system. Section B provides an update on the growth and composition of the financial sector. Section $\mathrm{C}$ assesses the exposure of the banking system to credit, exchange rate, interest rate, liquidity and real sector risks; examines the capital adequacy and profitability of banks; and tests their resilience under various hypothetical stresses.

3. The rapidity of credit growth in Latvia continues to be a source of potential vulnerability, as it is in many countries of Eastern Europe and East Asia (see IMF, World Economic Outlook April 2004, Chapter IV). Section D of the present chapter therefore explores the prudential controls that may be used to ensure that the transition to a more sustainable rate of credit expansion is a smooth one. It discusses various prudential measures individually, and goes on mention factors which affect the efficacy of all prudential actions.

\section{B. Recent Changes in the Financial Sector}

4. Financial institutions' assets have expanded rapidly, mainly on account of credit growth, reaching 94 percent of GDP at the end of 2003, compared with 59 percent just three years earlier. However, bank credit to the private sector remains only about half the banks' asset portfolio, and is equivalent to 44 percent of GDP. Banking remains the dominant financial activity, with banks accounting for an estimated 90 percent of financial assets. The remainder is accounted for by insurance companies and leasing, while credit unions and pension funds have tiny shares (see Table III.1).

\footnotetext{
${ }^{1}$ Prepared by DeLisle Worrell. The mission gratefully acknowledges the contributions of Dr. Medvedevshiha, Ms. Ivanova and the staffs of the BoL and the FCMC, who prepared the stress tests.
} 
5. Foreign banks with headquarters in the EU now own majority shares in Latvian banks, in an amount that comprises 54 percent of total banking capital, and the remainder is in domestic private hands, except for a share of about 6.5 percent, owned by the government. Most of this represents the capital of the Latvijas Hipoteku un Zemes bank, which has successfully married development and commercial banking activity, and has remained profitable.

6. The degree of concentration in the banking system remains relatively high, with the 5 largest banks, in terms of deposits, having over half the market for deposits, loans and total assets. The 10 largest banks, in terms of deposits, account for 85 percent of total deposits. There are 23 banks operating in Latvia.

7. Leasing has been the fastest growing method of financing consumer durables and transport equipment. Three banks offer leasing services, in addition to other banks which have leasing subsidiaries, and there are a number of nonfinancial enterprises which also offer leases. The lats volumes outstanding with the leasing subsidiaries of banks, and with nonfinancial firms, are estimated at about 2 percent of GDP.

8. The total investment assets held by insurance companies at September 2003 (the most recent data posted by the FCMC) were equivalent to 2 percent of GDP. The contributions of credit unions and private pension fund assets (other than their balances with commercial banks, included with bank deposits) were very small, less than $1 / 2$ percent of GDP.

\section{Banking Stability Assessment}

\section{Capital adequacy and profitability}

9. The risk-weighted capital adequacy ratio (CAR) for the banking system remains comfortably above the FCMC's stipulated minimum of 10 percent (see Table III.2). A decline in the CAR, from 14 percent at the time of the FSAP (end-2001) to 12.5 percent at the end of the first quarter of 2004, reflects the extraordinary pace of credit growth, given that bank capital and reserves increased by more than 50 percent over that period. Major banks with access to the international market claimed that their issues of new capital in 2003 were oversubscribed, and that their capital market advisors recommended that they increased the size of the issue; however, they declined because the amount offered provided ample funding for their prospective needs. However, one bank reported that its most recent lats bond issue, early in 2003, was too expensive in view of the returns available in the competitive credit market, and that, since that issue, it has supplemented its deposits by funding from its foreign head office. Other banks also reported slow uptake of bonds issued in lats.

10. Banks continue to be profitable, even though returns have declined slightly, with the interest margin falling in response to competitive pressures. The return on equity (RoE) for 2003, at almost 17 percent, was down 2 percentage points from the end of 2001, but there 
was a recovery in the first quarter of 2004. The proportion of bank income derived from fees for services has increased only slightly (by 2 percentage points) to almost 25 percent.

\section{Credit, overheating, and financial risk}

11. This sub-section begins with an analysis of the potential of credit growth to cause overheating, in the sense of contributing to general price inflation, or creating expectations of future general price inflation. The second part of the sub-section deals with the increased financial sector risk, as a result of the rapid credit growth, and the resilience of banks in the face of a deterioration of credit.

\section{Credit expansion and overheating}

12. The evidence on overheating is drawn from international comparisons of credit to GDP ratios, international comparisons of household debt loads, unpublished indicators of housing prices, rental prices included in the CPI, econometric predictions of credit growth, data on the funding of new credit, inferences from credit to the construction sector, and the results of interviews with the managements of leading banks in Riga.

13. At the end of February 2004, the annual growth rate of credit to the private sector was above 40 percent, with household credit, mostly for mortgages, growing most rapidly, although the level of credit for corporates was larger. However, the ratio of private sector credit to GDP for Latvia remains low, compared to the ratio for a selection of European countries (see Figure III.1). The average for the euro area is 113 percent, and, apart from transition economies and Turkey, the lowest ratio is Finland's 65 percent. Although household credit grew at the rate of 77 percent in 2003, the third year the growth rate has been over 50 percent, the ratio of household debt to GDP at year end was only 21 percent, compared with the European average of 57 percent (Austrian National Bank, 2003). The ratio of household debt to disposable income for most industrial countries is over 100 percent. Cottarelli, Dell'Ariccia and Vladkova-Hollar (2003) indicates that private sector credit in Latvia remains below the expected level, given the country's per capita income, debt/GDP ratio, inflation record, degree of financial liberalization, and the level of its legal/regulatory/corporate culture. The fact that these indicators are low suggests that, for the present, there remains potential for credit to grow rapidly, without significantly increased risk of macroeconomic instability, provided that regulatory and supervisory capability is adequate, financial risks are well managed, and financial indicators are closely monitored.

14. Based on unpublished data extracted from the land title registry by the Bank of Latvia, inflation in housing prices decelerated rapidly in 2003, and prices in the fourth quarter were significantly lower than a year earlier. However, average inflation of housing prices for 2003 as a whole was still over three times the rate for general inflation (Table III.2). To date, rental prices included in the CPI have not reflected this pattern of higher than overall inflation. The deceleration of real estate inflation is consistent with discussions with bankers, the majority of whom indicated that the increasing supply of new apartments was easing housing supply pressure, and that prices of older Soviet-style 
apartments from the 1960s had either stagnated or had begun to fall. Data compiled by the BoL indicates that apartment prices in Latvia are among the lowest (in relation to per capita income) in a comparison with selected countries, including major industrial and European countries. Apartment prices in Latvia are 8 percent (of per capita income) per square meter, compared with a range of 7-21 percent (see Figure III.2). A similar comparison for major cities illustrates the fragmentation of the market in Riga: apartment prices start at a low of 20 percent of national per capita income for "housing districts," rising to 34 percent outside Riga centre, and with a range of 39-72 percent for Riga centre, vs. a range of 20-94 percent for comparator cities (see Figure III.3).

15. The increase in credit to the private sector is funded by sustainable sources - deposit growth, bond flotation on the euro market, and credit lines extended by foreign banks with subsidiaries in Latvia - rather than by money creation by the Bank of Latvia. In 2003 private credit grew by LVL 885 million, an amount that was overfunded by the combination of an increase in deposits of LVL 660 million, and financial inflows equal to LVL 380 million.

16. A bias toward rapid growth in credit to land development companies, in preference to individual household mortgages, might indicate the presence of land development speculation, which might in due course contribute to inflation. In contrast, more moderate growth in land development credit might indicate growth in the supply of housing, which would alleviate inflationary pressures. Lending to land development companies is not readily available, but credit to the construction sector grew at 33 percent, a little more slowly than for credit to the private sector as a whole.

17. In discussions with the management of six commercial banks (including the four largest), the bankers' association, and the lessors' association, the mission found general concern about the recent increase in inflation, but no-one thought that credit growth had contributed to this increase. The acceleration of inflation was attributed to adjustments in regulated prices, stockpiling in anticipation of tax changes as a result of EU accession, and general apprehension about the risk of a jump in prices on accession. Although mortgages are their fastest growing business, bankers argued that the market remains underdeveloped, by international standards. One banker claimed that only about 20 percent of workers have incomes high enough to qualify for them for mortgages, and only a minority of these already had loans. A majority of bankers were of the view that inflation in the real estate market was sustainable, apart from apartments in the Old Town of Riga, and speculative land purchases in the suburbs.

\section{Credit expansion and financial system vulnerability}

18. A rapid increase in credit may be accompanied by increased levels of financial risk, in a situation where banks need to expand lending aggressively to maintain profitability. The authorities are fully aware of this possibility, and have advised the banks and the bankers' association accordingly. In discussions with bankers the mission found an awareness of the risks, and of the need to maintain high standards of credit evaluation. However, the ratio of 
NPLs to total loans is very low (1.5 percent at end-March 2004) and provisions have been made for 89.4 percent of these NPLs.

19. It is not possible, at the present time and with the indicators available, to determine the probability of deterioration of credit quality. Under these circumstances it is common practice to employ stress tests, to determine the resilience of the banking system to a worsening of the loan portfolio which, however unlikely, is feasible. The mission made a presentation on stress testing methodology currently employed by the Fund, to staff of the BoL and the FCMC, who completed stress tests for all banks, for a deterioration of their loan portfolio.

20. A test was done to determine the potential impact of a shock to the banks' real estate portfolios, which increased their NPL ratio (to total loans) by an amount equivalent to 30 percent of the real estate portfolio. No bank would become insolvent under these circumstances, but three banks, accounting for 13 percent of banking assets, would fall below the FCMC's minimum capital requirement, as a result of additional provisions they would have to make to cover losses. They would need a total of LVL 4 million to repair the breach. Sensitivity tests were also undertaken for cases where the proportion of NPLs in each bank doubled and tripled, and where each bank's NPL ratio rose to 5 percent. In none of these cases was any bank at risk for insolvency; in the worst case 3 banks - with 27 percent of banking system assets - fell below the minimum 10 percent CAR required by the FCMC, but they needed only LVL 6.9 million of additional capital to repair the breach, and the losses to the banking system as a whole amounted to no more than 0.9 percent of banking system assets.

21. The ratio of household debt to GDP continued to rise very rapidly, increasing to 14.8 percent at end-March 2004, from 9.1 percent at end-December 2003. The number of applications for protection from creditors by enterprises rose 21 percent in 2003 , but the ratio of insolvencies to new enterprises established remained unchanged at 17 percent. The household debt to GDP ratio remains very low by comparison with emerging market countries and EU members. However, the proportion of bankruptcies to new enterprise has increased somewhat, compared to the previous 2 years (Table III.2).

\section{Exchange rate risk}

22. The banking system had a short net open position (NOP) at end-March 2004, equivalent to 7 percent of capital. Banks have a degree of protection against exchange rate risk through the mandatory NOP limits set for them under the Law on Credit Institutions (10 percent of capital for any one currency, and 20 percent for the total exposure). Bankers interviewed by the mission considered the current exchange rate appropriate, and expected no adjustment in the peg, even though the spread between interest rates on items denominated in lats, and on comparable items denominated in dollars and euros, widened steadily in 2003, for maturities up to 6 months. The spread on one-year maturities narrowed in the second half of the year, however. 
23. In light of the impending repegging of the lats to the euro, the recent volatility dollar-euro exchange rate, and uncertainty about the future rate, are cause for concern. Because of the dominant weight of the U.S. dollar in the SDR basket, it is the lats-euro exchange rate which has shown greater volatility. The standard deviation of monthly changes in the lats-euro rate for 2003 was one and a half times that for 2002. The standard deviations of the lats-euro and lats-dollar exchange rates were about the same in 2002 (Table III.2). The NOP limits protect banks from excessive direct risk exposure as a result of these fluctuations, and some bankers interviewed by the mission claim to operate with even tighter guidelines than those specified by the FCMC. However, banks remain exposed to indirect losses through their loans to borrowers who may be at risk of loss from this exchange rate volatility.

24. Stress tests undertaken by the BoL and the FCMC confirmed the resilience of all banks to exchange rate changes. Tests were carried out for changes in the euro-dollar exchange rate, because it is not possible to reliably estimate the probability of any given change, and for a devaluation of the lats, which is feasible though highly improbable. Three alternatives were considered: a 40 percent depreciation of the lats against the U.S. dollar, a 20 percent devaluation of the lats against the SDR peg, and a 10 percent depreciation of the dollar against the euro. (These changes would be set off by an external shock, by assumption.) In none of these circumstances does any bank fall below the 10 percent minimum capital asset ratio, and the aggregate losses are always trivial, less than 0.1 percent of banking assets. However, these results are for the direct impact only, and do not take account of any losses that bank borrowers might sustain as a result of these exchange rate changes. Such losses could be very large, particularly in case of a change in the SDR peg, which might have adverse effects on investor confidence and capital flows.

\section{Liquidity and foreign currency deposits}

25. Liquidity risk in the Latvian banking system appears to be somewhat higher for nonresident deposits, which are more volatile than resident deposits. The standard deviation of changes in nonresident deposits is 1.4 times that of resident deposits, with nonresident deposits accounting for 54 percent of total deposits, a proportion that has remained unchanged in the past 2 years. In order to minimize their risks of illiquidity banks maintain a high ratio of liquid assets to total deposits, 62 percent at end-March 2004. These liquid assets were the equivalent of 92 percent of nonresident deposits (Table III.2). Bankers interviewed by the mission have treasury management functions which use a risk-weighted approach to manage their current assets, taking into account the volatility of deposits, both of residents and nonresidents.

\section{Interest rate risks}

26. Interest rate risks may arise for financial institutions when they are required to increase rates on deposits sooner than they can make corresponding changes in the interest they charge on assets. In the case of Latvian banks, pure interest rate risk is contained, because marketable securities comprise almost 40 percent of bank assets, and loans are typically quoted as a percentage over a variable reference rate, either Libor, the Rigibor or 
the eurobor. The BoL and FCMC undertook a stress test for all banks, assuming a 10 percentage point increase in interest rates. Conservative assumptions were made about the time to repricing of loans, for those loans for which data are not currently available. Assumptions were chosen such that the actual time to repricing is almost certainly much shorter than the time used in the assumptions. The interest rate shock would put only 1 bank, with 7 percent of the system's assets, below the 10 percent CAR, and that bank would need somewhat less than LVL 3 million to return to compliance. Losses to the banking system would be the equivalent of 0.5 percent of banking assets.

\section{Real sector risks}

27. Real sector risks are diversified, because, apart from households, bank lending is not concentrated in any one economic sector, and a shock affecting only one sector would therefore not cause credit deterioration sufficient to be a source of vulnerability for the system as a whole. The BoL and FCMC conducted stress tests for real external and real internal shocks. The external shock was assumed to be large enough to require provisioning for 30 percent of loans to the manufacturing, transport and telecommunications industries. Even in the event of this very severe shock, no bank would become insolvent, and the aggregate loss to the banking system would be just about 1 percent of banking assets. Two banks, with 31 percent of banking assets, would fall below the minimum CAR, and together they would need to acquire almost LVL 7 million in new capital in order to return to full compliance. The domestic shock applied was even more extreme, requiring provisions for 30 percent of the portfolio lent to firms in construction, trade, real estate, renting and business activities. Even under this stress no bank becomes insolvent, and the loss to the banking system is about 2 percent of assets. Five banks would fall below the minimum CAR, and the amount of additional capital needed would be substantial, LVL 41 million.

\section{Other financial soundness indicators}

28. The most recent ratings of Latvian banks by international rating agencies have been favorable, with stable or positive outlooks and an upgrade in one case. The three largest banks are rated both by Fitch Ratings and by Moody's, and three other banks are rated by one or the other agency.

\section{Prudential credit controls}

29. There is widespread concern about the pace of credit growth in Latvia, on the part of the authorities and the managers of financial institutions, even though there are no signs of credit-induced inflation, or of a deterioration in credit quality, to date. International experience suggests that the current rate of credit growth is unlikely to be sustained, and policies may be needed to smooth the transmission to a more sustainable pace. The first initiative in this direction, in March 2004, was a 50 basis point increase in the BoL's discount rate. This pushed up mortgage rates in lats, as intended, but, rather than slower lending growth, the result was a switch to cheaper euro and dollar denominated mortgages. This shift 
increases systemic risk, by virtue of the increasing proportion of borrowers whose earnings are not in the currency that matches their loan obligation.

30. The authorities have turned their attention to prudential measures, as an alternative means of slowing the pace of credit growth. Possible tools of prudential correction include: adjustment to capital adequacy guidelines; requiring additional provisions for some or all loans; requiring additional collateral for some or all loans; and stipulating lower loan-to-value ratios.

\section{Tightening capital adequacy guidelines}

31. Banks' CAR at end-March 2004 stood at 12.5 percent, compared with the minimum required 10 percent, so the CAR would need to be raised more than 2.5 percentage points in order to have an effect. However, it is unclear whether increasing the CAR beyond this point would have an effect on overall credit growth. Banks' preferred response, mentioned in discussions with the mission, would be to raise additional capital. Banks with good access to international financial markets (banks with good credit ratings, and subsidiaries of foreign banks ${ }^{2}$ ) anticipate no difficulty in raising additional capital, and the single foreign branch would be unaffected. Banks whose access to international markets is limited will not necessarily be restricted, because it has been possible to raise funds on the local market, though at increasing cost. To the extent that an increase in the CAR requirement inhibits the lending of locally capitalized banks, it makes them less competitive with banks with access to international finance, without affecting the pace of overall credit growth.

\section{Requiring additional provisions}

32. It is prudent that banks take extra security against credit risk exposure in an environment of rapid credit expansion, which is inherently more risky. One method of doing so is to make an additional general provision, in proportion to the entire loan portfolio. The FCMC does not require provisions to be set aside for standard loans, although some banks follow this practice. Based on credit to the private sector at December 2003, a one percent provision on the entire loan portfolio for the system was LVL 28 million, the equivalent of 39 percent of banks' profits in 2003. A cutback in lending would not necessarily be seen as the best way to maintain profitability, if such a provision were to be imposed. Banks might choose instead to accelerate the growth of lending, to generate returns on increased loan volume, provided they could raise the additional capital they would require. As for the previous measure, banks with limited access to international financial markets might lose market share to those with access to international markets, or to foreign banks, with little or no impact on overall credit growth.

\footnotetext{
${ }^{2}$ Foreign subsidiaries which are financed by lines of credit from overseas offices would merely need to adjust their accounts by moving an amount from the item "due to banks abroad" to the item "owner's equity," with no change in operations.
} 


\section{Requiring additional collateral}

33. Prior information on banks' existing practices would be needed, in order to determine a minimum stipulated level for collateral, that might have an impact on aggregate credit levels. Moreover, collateral guidelines vary according to type of security, currency denomination of the loan, maturity of the credit, track record of the borrower, and other characteristics of each credit, so the impact of imposing a minimum requirement is uncertain. Depending on bank practices and borrower characteristics, the stipulated minimum may apply to few credits, and may therefore have little effect on the overall credit demand.

\section{Stipulating lower loan-to-value ratios}

34. Stipulations for minimum down payments on consumer durable loans, minimum owners' equity participation in mortgages, and similar rules, were once popular with central banks, both in industrial and developing countries, but proved relatively easy to evade, in many countries. Credit demand and financing were often diverted to insurance companies, leasing companies, credit unions, suppliers, factoring arrangements, and/or informal channels and instruments. Moreover, the practices employed to get around the controls may increase systemic risks, for example, the financing of a single transaction by multiple credits, some of which may not be fully disclosed, and may not be offered at appropriate terms, or by formal financial institutions. However, tightening loan-to-value guidelines is advisable as a measure to limit individual banks' risk exposure, particularly in volatile segments of the real estate market. Some banks reported to the mission that their guidelines already provided lower loan-to-value limits for riskier loans, including foreign currency loans, loans for land purchase, and loans for the most inflation-prone areas of Riga. Increased vigilance by FCMC inspectors, and attention to systems and guidelines for asset valuation, documentation and certification, are recommended.

\section{Currency matching for bank borrowers}

35. The FCMC should encourage banks to match the currency denomination of loans to the currency of the borrower's earnings, as far as possible, so as to minimize indirect risk exposure. In theory, this could have an effect on overall credit growth, if potential borrowers have to accept a reduced principal amount in lats, compared to what they might have borrowed in euro or U.S. dollars, for a comparable debt service burden. However, the possibility cannot be discounted that borrowers might seek to finance the difference in principal, between the foreign currency and lats loans for which they are eligible, by other, more short term financing arrangements. This tool, like those mentioned earlier, is probably more useful for risk mitigation by individual banks, than for overall credit control.

\section{Prudential controls in general}

36. The above discussion highlights those measures for increased prudential surveillance which are advisable to reduce individual bank risk in a climate of rapid credit expansion. 
However, prudential controls all share the following limitations which may render them ineffective as measures to slow the growth of credit, at the aggregate level:

- $\quad$ They limit credit only for banks which are unable to increase their capital. The largest banks in Latvia reported that they have recently raised funds at home and abroad without difficulty, that their recent offers have been oversubscribed, and that they could readily expand capital, though at some additional cost, in the case of locally financed banks.

- Equivalent regulations would be required across all financial institutions (banks, leasing companies, credit unions, insurance companies, and possibly others), to avoid regulatory arbitrage. For example, a prudential measure which limited bank credit, without reducing credit demand, would tend to divert incremental demand to leasing companies, and to finance companies associated with wholesale and retail firms.

- $\quad$ Restrictions have the potential to divert credit demand to less well regulated segments of the financial market and to informal finance, thereby increasing systemic risks.

- Given the fact of an open financial market, it is impossible to prevent the inflow of financing, even if the measures slow the intermediation of that financing through the domestic banking system. Corporations and high-worth individuals who are not fully accommodated by the domestic banking system may borrow abroad. This is particularly the case for international trading firms, for whom the balance of foreign trade credit and domestic borrowing for working capital is an ongoing treasury function. If working capital becomes more limited (or more costly) they may readily switch to additional trade credit.

- $\quad$ The measures may change incentives and competitive advantages in ways that are unintended, as between local and foreign owned institutions, with respect to risk management practices, as between financial institutions and other providers of credit (such as suppliers and traders), as between credit and other financial arrangements (such as leasing and factoring), and as between formally regulated financial markets and informal financial arrangements.

\section{E. Conclusions}

37. The mission confirmed that the banking system remains well capitalized, profitable and liquid, and found continued concern about the sustainability of rapid credit growth and the risk of increased volatility of nonresident deposits. Although the growth of credit continues to be very rapid, it has not contributed to inflation, and does not appear to have given rise to expectations of future inflation. Rapid credit growth has not led to a deterioration of credit quality either, and the ratio of NPLs to total loans remains very low. Moreover, the NPLs are 90 percent provided for, and the banking system could accept some deterioration in credit quality without falling below the FCMC's minimum capital adequacy requirement. Nevertheless, the extent to which household debt capacity has been impaired is 
not known, and the rapid credit growth remains a potential source of vulnerability. As the authorities continue to seek to implement policies to ensure a slowdown, intensified prudential surveillance is advisable.

38. The current exchange rate peg to the SDR is stable, financial markets are fully informed about the planned conversion to an euro peg in January 2005, and the conversion process is expected to be a smooth one. However, there remains uncertainty about the future of the dollar-euro exchange rate, and therefore about the forecast for the euro price of lats.

This implies an unknown exchange rate risk for banks with uncovered exposures in euro and dollars, up to the time of conversion, and for positions in dollars and other non-euro foreign currencies thereafter. This risk is contained by the FCMC regulation which limits each bank's overall NOP to 20 percent, with a limit of 10 percent per currency. However, indirect risks remain, from exposures to clients who are vulnerable to losses in case of adverse exchange rate movements. Nonresident deposits are more volatile than are residents' deposits, and banks need to manage asset and liability maturities carefully, so as to minimize their exposure to the risk of illiquidity. 


\section{References}

Austrian National Bank, November 2003, Financial Stability Report 6.

Cottarelli, Carlo, Giovanni Dell'Ariccia and Ivann Vladkova-Hollar, November 2003, "Early Birds, Late Risers, and Sleeping Beauties: Bank Credit Growth to the Private Sector in Central and Eastern Europe and the Balkans," (IMF WP/03/213).

International Monetary Fund, Country Report No. 02/67, March 2002, "Republic of LatviaFinancial System Stability Assessment." 
Table III.1. Financial System Structure

\begin{tabular}{lcccc}
\hline $\begin{array}{c}\text { Financial } \\
\text { Institutions }\end{array}$ & $\begin{array}{c}\text { End-2000 } \\
\text { Assets, LVL m. }\end{array}$ & \% of GDP & $\begin{array}{c}\text { End-2003 } \\
\text { Assets, LVL m. }\end{array}$ & \% of GDP \\
\hline Banks & 2,485 & 53 & 5,717 & 90 \\
Credit Unions & 1 & -- & 4 & -- \\
Insurance co's 1/ & 115 & 2 & 107 & 2 \\
Pension Funds 2/ & 6 & -- & 1 & -- \\
Leasing co's 3/ & 140 & 3 & 112 & 2 \\
All Fin. Insts. & & 59 & 5,914 & 94 \\
Credit to Private & & & 2,786 & 44 \\
Sector & & & & \\
\hline
\end{tabular}

Sources: Bank of Latvia, FCMC.

Notes:

1/ Data for September 2003.

2/ Private pension fund assets not held on deposit with banks.

3/ Mission estimate, 2003. Not comparable with 2000, because data unavailable to separate out leasing included on some banks' balance sheets. 
Table III.2. FSIs for Latvia

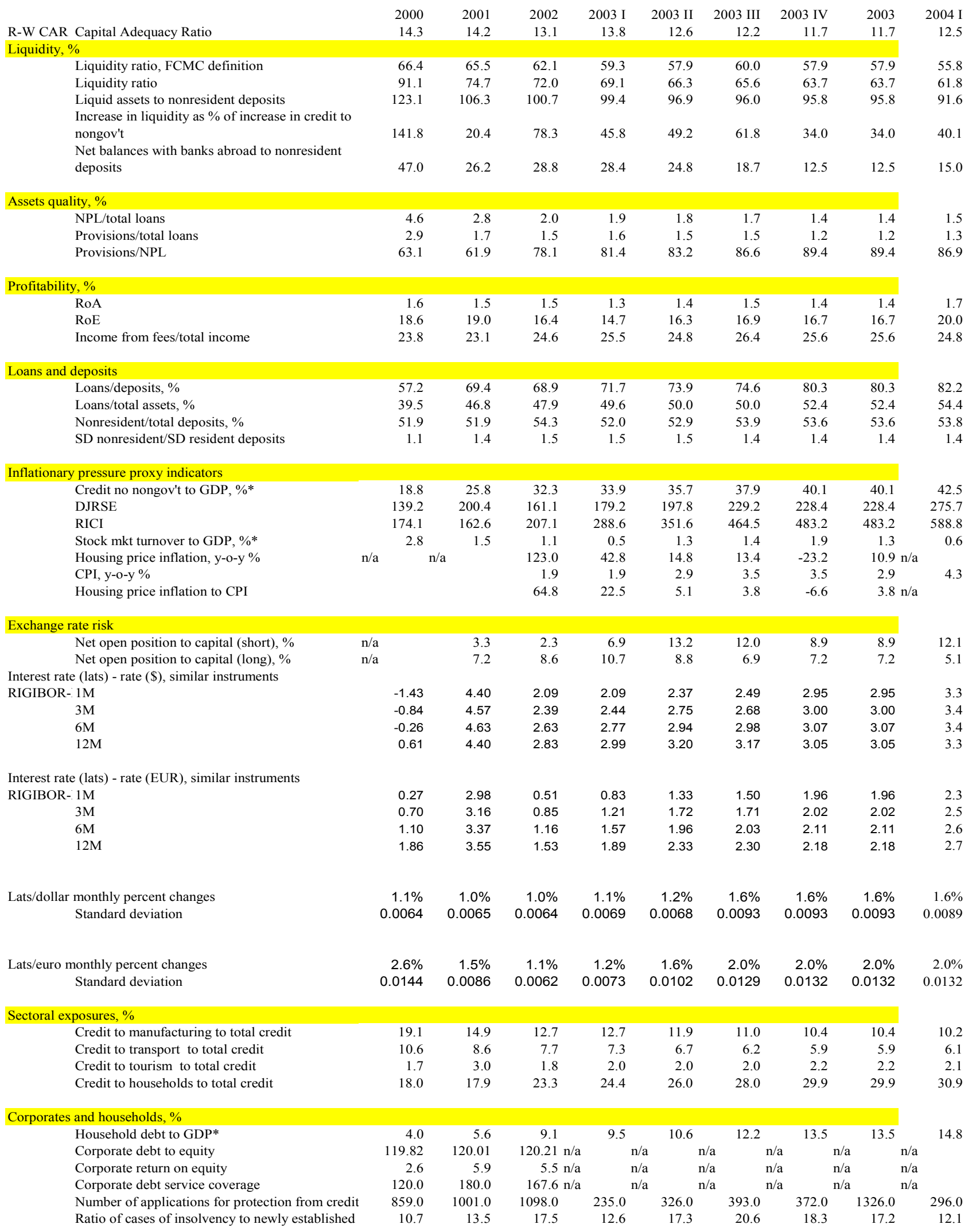

Source: BoL 
Figure III.1. Credit to Private Sector to GDP

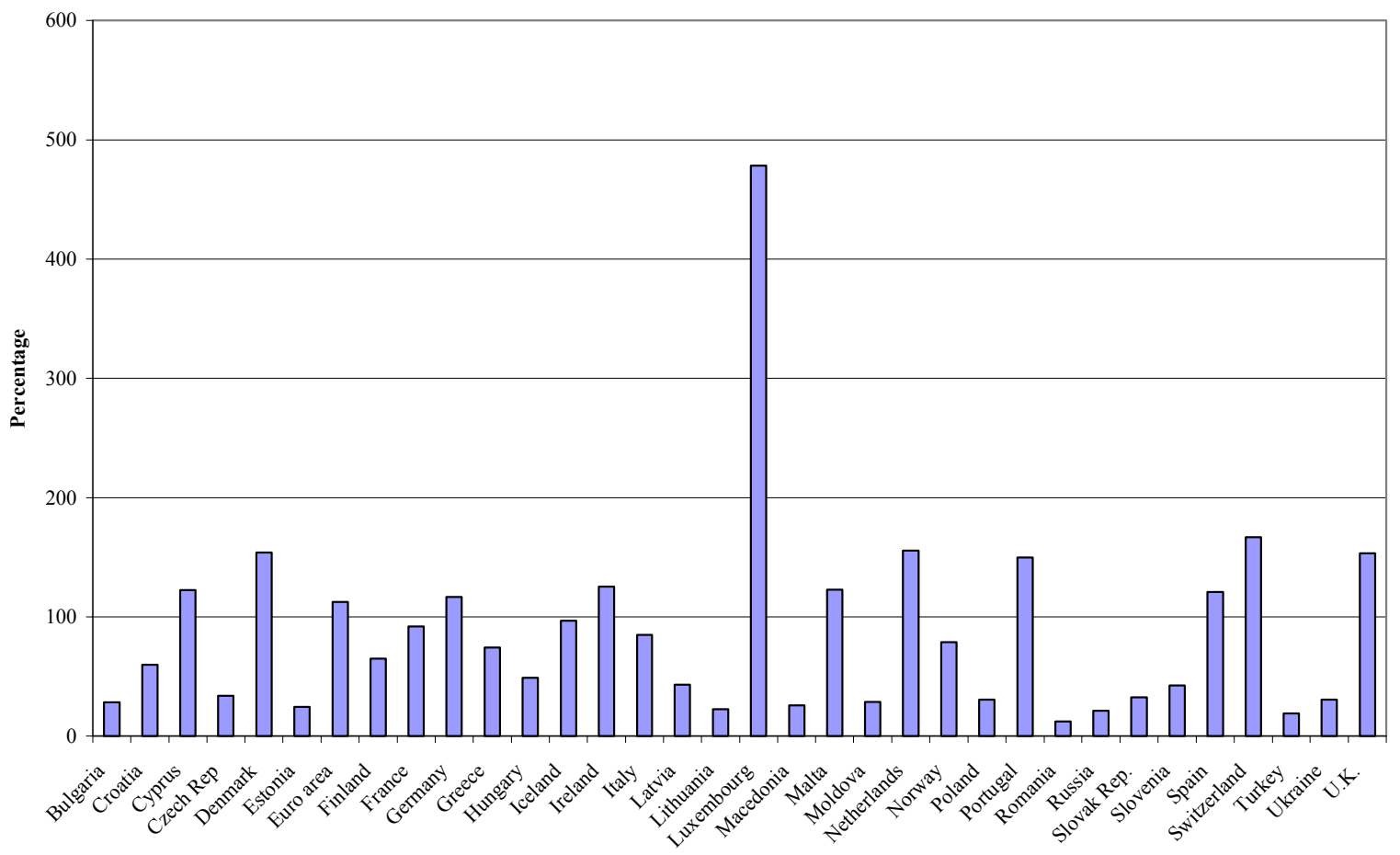

Figure III.2. Apartment Price Comparisons-Countries

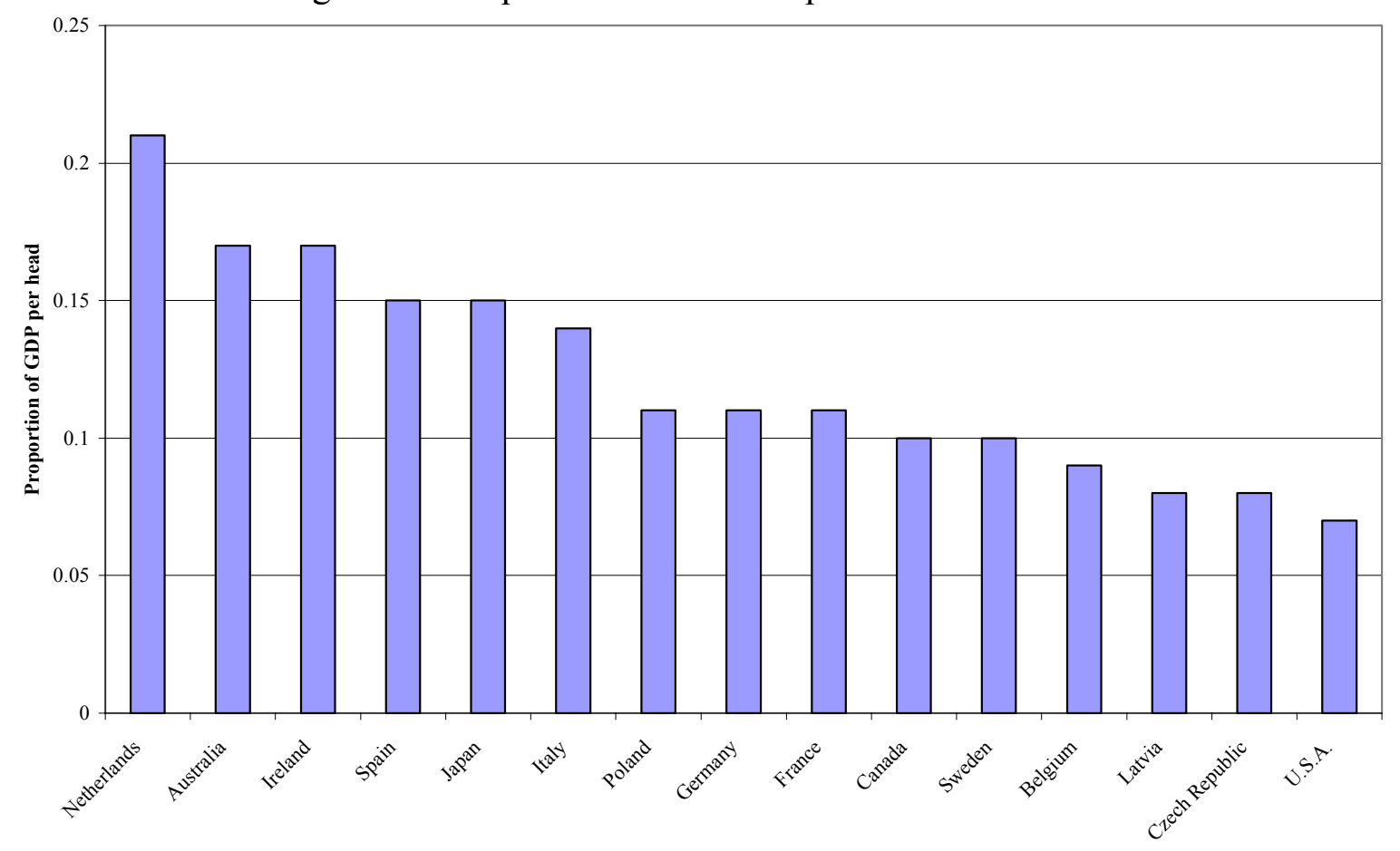


Figure III.3. Apartment Price Comparison-Cities

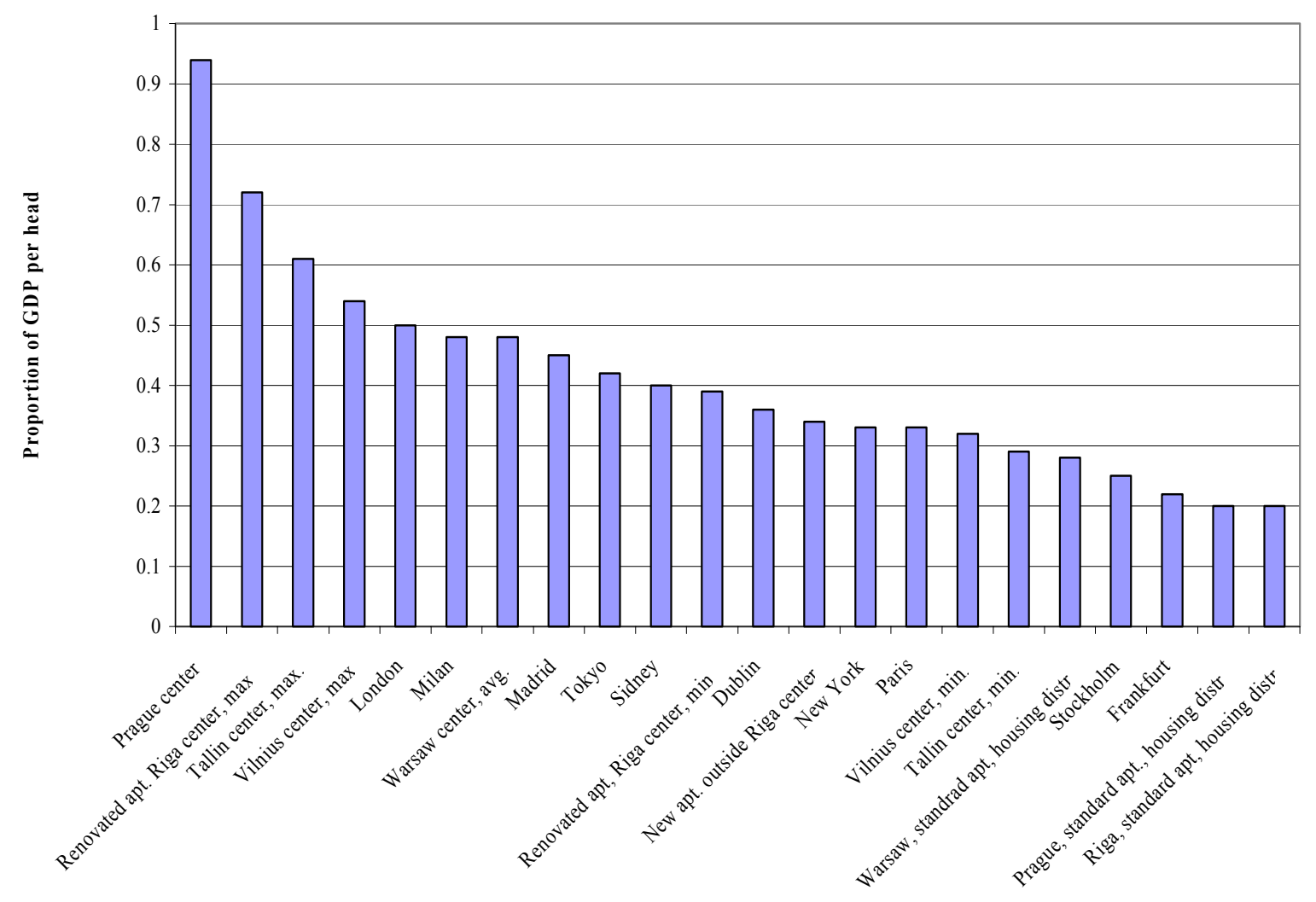




\section{Structural Budget Balance In LATVia ${ }^{1}$}

\section{A. Introduction}

1. This chapter presents estimates of the structural budget balance. These are necessary for the purpose of assessing the fiscal policy stance, as the actual budget balance is distorted by the influences from cyclical movements of output. This study is also conducted against the background of the accession of Latvia into the European Union (EU), since the structural budget balance, as well as the potential output, is featured in the EU macroeconomic surveillance procedures and has acquired "operational" status in the Stability and Growth Pact.

\section{B. Estimating Potential Output}

2. The structural budget balance analysis addresses the question: What would the budget balance be if output were at its potential level? Answering this question thus involves estimating the potential output as the preliminary step in the analysis.

3. The potential output is the level of output that could be obtained if the economy were operating at normal capacity. There are two general approaches to measuring the potential output. The standard approach used by the EC and a number of IMF country teams (especially for transition economies and developing countries) has been statistical detrending, for example, fitting a stochastic trend to the output data using the Hodrick-Prescott (HP) filter. This is the only feasible method for countries with insufficient data to attempt more sophisticated procedures. But being a pure statistical approach, its link with the economic concepts of potential output and business cycle is not very clear. ${ }^{2}$

4. A more theoretically appealing methodology is the production function approach, which involves estimating a production function, such as a Cobb-Douglas function of labor, capital, and technology. This approach is used by IMF country desks for a number of advanced economies, and a recent report by European Policy Committee (2001) has recommended that EU countries adopt this approach. However, the production approach is quite data demanding, requiring estimates of potential capital stock, structural employment, the level of education, and trend growth of total factor productivity (TFP). It is especially challenging to apply this approach to a transition country like Latvia, where reliable data on the capital stock and TFP are not available, and too many assumptions are needed to obtain any results.

\footnotetext{
${ }^{1}$ Prepared by Yuan Xiao.

${ }^{2}$ Another deficiency of the HP filter procedure is the so-called end-point problem, i.e., the estimated trend tends to differ if the values of the last observations change since there is no information about the persistence of the last observations.
} 
Table IV.1. Latvia: Structural Budget Balance 1/

\begin{tabular}{|c|c|c|c|c|c|c|c|c|}
\hline & 1998 & 1999 & 2000 & 2001 & 2002 & 2003 & $\begin{array}{l}2004 \\
\text { Proj. }\end{array}$ & $\begin{array}{l}2005 \\
\text { Proj. }\end{array}$ \\
\hline \multicolumn{9}{|c|}{ (In millions of lats, unless stated otherwise) } \\
\hline Real GDP & 4244.1 & 4383.6 & 4685.7 & 5061.0 & 5387.3 & 5788.9 & 6165.2 & 6535.1 \\
\hline Growth rate (percent) & 4.7 & 3.3 & 6.9 & 8.0 & 6.4 & 7.5 & 6.5 & 6.0 \\
\hline Potential real GDP (H-P filter) & 4219.8 & 4466.0 & 4744.6 & 5058.4 & 5401.8 & 5766.1 & 6140.4 & 6517.6 \\
\hline Growth rate (percent) & 5.7 & 5.8 & 6.2 & 6.6 & 6.8 & 6.7 & 6.5 & 6.1 \\
\hline Output gap (as percent of potential) & 0.6 & -1.8 & -1.2 & 0.1 & -0.3 & 0.4 & 0.4 & 0.3 \\
\hline Nominal GDP & 3902.9 & 4224.2 & 4685.7 & 5168.3 & 5691.1 & 6322.5 & 7002.8 & 7645.6 \\
\hline Potential nominal GDP & 3880.6 & 4303.6 & 4744.6 & 5165.6 & 5706.5 & 6297.6 & 6974.6 & 7625.2 \\
\hline Revenue & 1528.7 & 1560.6 & 1623.1 & 1696.9 & 1876.2 & 2108.7 & 2371.3 & 2657.9 \\
\hline Expenditure & 1553.5 & 1706.9 & 1763.7 & 1804.4 & 2030.6 & 2239.2 & 2494.4 & 2759.4 \\
\hline Net lending & 2.6 & 6.9 & -0.2 & -2.7 & -15.3 & -26.3 & -20.6 & -2.2 \\
\hline Fiscal balance & -27.4 & -153.2 & -140.4 & -104.9 & -139.1 & -104.2 & -102.6 & -99.2 \\
\hline Fiscal balance as $\%$ of GDP & -0.70 & -3.63 & -3.00 & -2.03 & -2.44 & -1.65 & -1.47 & -1.30 \\
\hline Change from previous year (percent) & $\ldots$ & -2.92 & 0.63 & 0.97 & -0.42 & 0.80 & 0.18 & 0.17 \\
\hline Unemployment benefits & 14.7 & 27.5 & 21.5 & 18.4 & 21.2 & 23.5 & 26.0 & 28.4 \\
\hline Registered unemployment rate (percent) & 7.6 & 9.7 & 8.4 & 7.8 & 7.9 & 7.6 & 7.6 & 7.6 \\
\hline $\begin{array}{l}\text { Assumed natural rate of } \\
\text { unemployment (percent) }\end{array}$ & 8.0 & 8.0 & 8.0 & 8.0 & 8.0 & 7.8 & 7.8 & 7.7 \\
\hline \multicolumn{9}{|c|}{ (In percent) } \\
\hline \multicolumn{9}{|c|}{ Scenario I: assuming revenue elasticity $=0.8$} \\
\hline $\mathrm{SBB}$ as $\%$ of GDP & -0.90 & -2.96 & -2.63 & -2.05 & -2.38 & -1.76 & -1.58 & -1.38 \\
\hline Change from previous year & $\ldots$ & -2.06 & 0.33 & 0.57 & -0.33 & 0.61 & 0.18 & 0.21 \\
\hline Cyclical balance (as \% of GDP) & 0.20 & -0.67 & -0.37 & 0.02 & -0.07 & 0.11 & 0.12 & 0.08 \\
\hline Change from previous year & $\ldots$ & -0.87 & 0.30 & 0.39 & -0.09 & 0.18 & 0.00 & -0.04 \\
\hline \multicolumn{9}{|c|}{ Scenario II: assuming revenue elasticity $=1.0$} \\
\hline SBB as $\%$ of GDP & -0.95 & -2.82 & -2.54 & -2.06 & -2.36 & -1.79 & -1.61 & -1.40 \\
\hline Change from previous year & $\ldots$ & -1.87 & 0.28 & 0.48 & -0.30 & 0.57 & 0.18 & 0.22 \\
\hline Cyclical balance (as \% of GDP) & 0.24 & -0.81 & -0.46 & 0.03 & -0.08 & 0.14 & 0.15 & 0.10 \\
\hline Change from previous year & $\ldots$ & -1.05 & 0.35 & 0.48 & -0.11 & 0.23 & 0.00 & -0.05 \\
\hline \multicolumn{9}{|c|}{ Scenario III: assuming revenue elasticity $=1.2$} \\
\hline SBB as \% of GDP & -0.99 & -2.68 & -2.45 & -2.06 & -2.34 & -1.82 & -1.64 & -1.41 \\
\hline Change from previous year & $\ldots$ & -1.69 & 0.23 & 0.39 & -0.28 & 0.53 & 0.18 & 0.22 \\
\hline Cyclical balance (as \% of GDP) & 0.29 & -0.95 & -0.54 & 0.03 & -0.10 & 0.17 & 0.17 & 0.12 \\
\hline Change from previous year & $\ldots$ & -1.24 & 0.40 & 0.57 & -0.13 & 0.27 & 0.01 & -0.06 \\
\hline \multicolumn{9}{|c|}{ Disaggregated approach (applying different elasticities to individual tax categories) } \\
\hline SBB as \% of GDP & -0.87 & -3.05 & -2.69 & -2.05 & -2.39 & -1.75 & -1.56 & -1.36 \\
\hline Change from previous year & $\ldots$ & -2.18 & 0.37 & 0.64 & -0.34 & 0.64 & 0.18 & 0.20 \\
\hline Cyclical balance (as \% of GDP) & 0.17 & -0.58 & -0.31 & 0.02 & -0.06 & 0.10 & 0.10 & 0.06 \\
\hline Change from previous year & $\ldots$ & -0.74 & 0.27 & 0.33 & -0.08 & 0.15 & 0.00 & -0.03 \\
\hline
\end{tabular}

1/ Based on estimates of the potential GDP by applying HP filter to the period 1995Q1-2005Q4. 
5. In this study, we take the stochastic detrending approach to measuring potential output, and apply the HP filter to seasonally adjusted quarterly real GDP series for the period 1995:Q1 to 2005:Q4. Projected 2004 and 2005 data are included to mitigate the end-point problem, i.e., to supply the algorithm with some guidance regarding the persistence of the 2003 GDP. We project real GDP to grow by 6.5 percent in 2004, which reflects the assumption that the higher-than-normal growth observed in 2003 signals a permanent rise in potential output.

6. Figure IV.1 plots the resulting estimates of the output gap, which is the percentage deviation of actual output from its potential level, for 1995-2003. The potential real growth rates and output gaps are also shown in Table IV.1. As can be seen, in 1998 the actual output was above the potential level, but the adverse impact of the Russia crisis depressed output to 1.8 percent below potential in 1999 and 1.2 percent below potential in 2000 . In fact, the economy started to recover in 2000, as evidenced by the high growth rate of 6.9 percent. But because of the significant negative output gap in 1999, the output level still did not reach potential in 2000 thus creating a negative output gap. The estimated output gap was slightly positive in 2001, -0.3 percent in 2002, and 0.4 percent in 2003.

Figure IV.1. Latvia: Output Gap

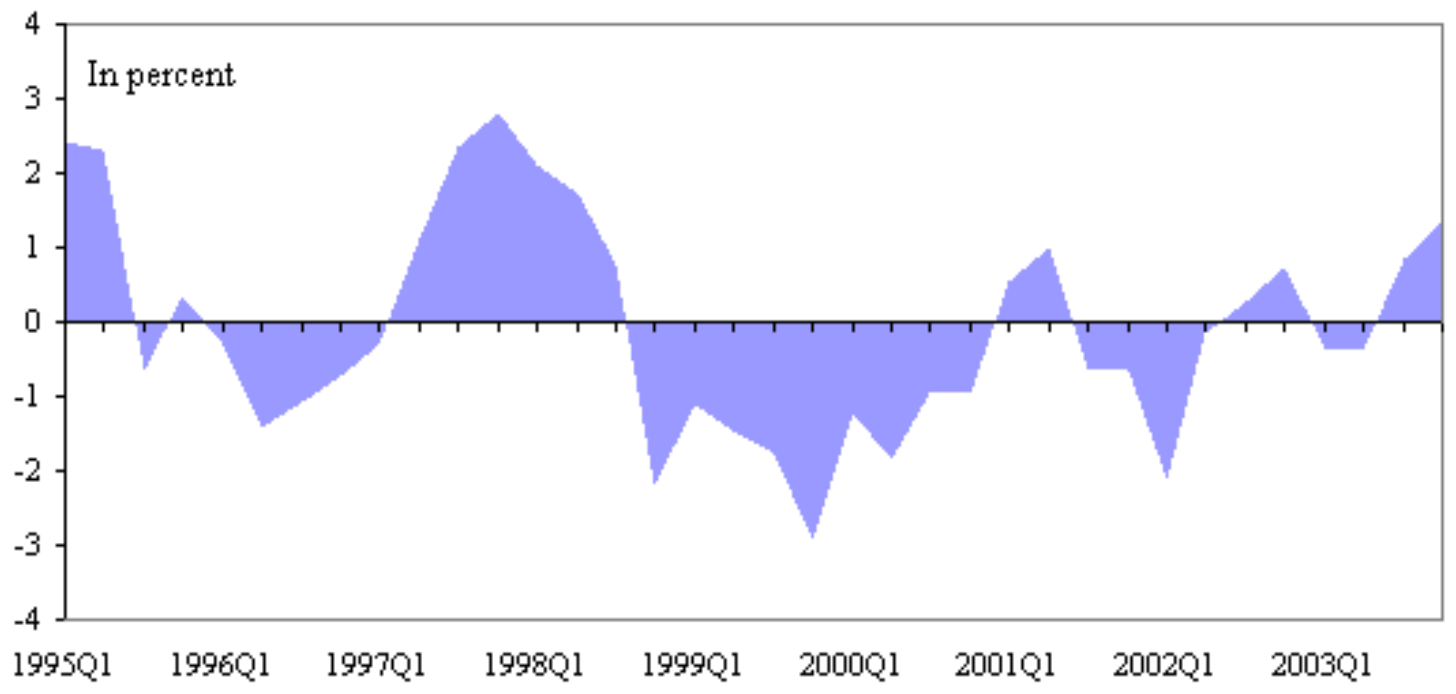




\section{Calculating Structural Budget Balance}

7. In calculating the structural budget balance, tax revenue needs to be adjusted since it depends directly on the output level. In the IMF's methodology (see Hagemann, 1999), on the expenditure side only outlays on unemployment benefits are assumed to be sensitive to the cyclical movement of output. Therefore, the structural budget balance can be expressed as follows:

$$
\begin{gathered}
S B B=T^{*}-G^{*}, \\
T^{*}=T \cdot\left(Y^{*} / Y\right)^{\varepsilon}, \\
G^{*}=G+U B \cdot\left(\frac{U^{*}-U}{U}\right) .
\end{gathered}
$$

8. In the above, $\mathrm{T}$ is tax revenue, $\mathrm{Y}$ and $\mathrm{Y}^{*}$ are the actual and potential levels of output, $\mathrm{G}$ is government expenditure, $\mathrm{UB}$ is the unemployment benefit payment, $\mathrm{U}$ and $\mathrm{U}^{*}$ are the actual and natural rates of unemployment, and $\mathrm{T}^{*}$ and $\mathrm{G}^{*}$ denote structural revenue and expenditure which are measured at the potential output. $\varepsilon$ is the elasticity of tax revenue with respect to income, therefore $\varepsilon \equiv \Delta T / \Delta Y$, and $T^{*} / T=\left(Y^{*} / Y\right)^{\varepsilon}$. Expenditure is adjusted by the cyclical component of the unemployment benefit payments.

9. The procedure for adjusting revenues varies in practice. One could adjust total revenue using a single revenue elasticity, or apply different elasticities for each type of tax. The revenue elasticity $\varepsilon$ is obtained by the regression $\log T=c+\varepsilon \log Y+e$ using country data, and often followed by judgmental adjustments. Although a unitary elasticity seems to be a reasonable assumption, in reality the elasticity could differ from unity owing to progressive tax rates and tax exemptions. Hageman (1999) estimated revenue elasticities for the euro area countries and some other advanced European countries. They range from 0.70 for the United Kingdom to 1.25 for Spain, with most in the range 0.9 to 1.1. In this study, we estimate the aggregate elasticity to be about 0.82 for Latvia, but we also report several different scenarios, as in Burgess (2001).

10. It is reasonable to expect that different components of taxes (corporate tax, personal income tax, social security tax, value added tax, etc.) may have different elasticities with respect to the output gap. Therefore another approach to calculating the structural revenue is to adjust each revenue component separately. Schmitz (2002) follows this approach. In this study we have also estimated these individual elasticities (Table IV.2), which are found somewhat smaller than those obtained by Schmitz (2002). The individual elasticities range from 0.63 to 1.12 , with an estimated aggregate elasticity, as noted above, of 0.82 .

11. The resulting estimates for the structural budget balance are presented in Table IV.1 and Figure IV.2. Given the uncertainty surrounding the revenue elasticities, we present three 
scenarios using the aggregate approach, under the assumptions that the revenue elasticity equals $0.8,1.0$, and 1.2, and we also report the results from the disaggregated approach. All four cases yield similar results, as can be observed from both Figure IV.2 and Table IV.1. As expected, the two sets of results that are the closest are those obtained from the aggregate method assuming a 0.8 elasticity, which is approximately the value of the aggregate elasticity estimated from the data, and the disaggregated method. To adjust the unemployment benefit payments, a path of the natural rate of unemployment needs to be assumed. However, the effects of changing this assumption can be ignored since the proportion of unemployment benefit payments in total expenditure is very small (about 1 percent).

Table IV.2. Latvia: Estimated Tax Elasticities

\begin{tabular}{lcc}
\hline & $\begin{array}{c}\text { Schmitz } \\
(2002)\end{array}$ & $\begin{array}{c}\text { New } \\
\text { estimates }\end{array}$ \\
\hline & & \\
Corporate income tax & 0.53 & 0.93 \\
Personal income tax & 2.02 & 1.12 \\
Social security contributions & 1.05 & 0.73 \\
VAT & 1.50 & 0.63 \\
Excises & 1.86 & 1.00 \\
& & \\
Total revenue & $\ldots$ & 0.82 \\
\hline
\end{tabular}

Figure IV.2. Latvia: Structural Budget Balance

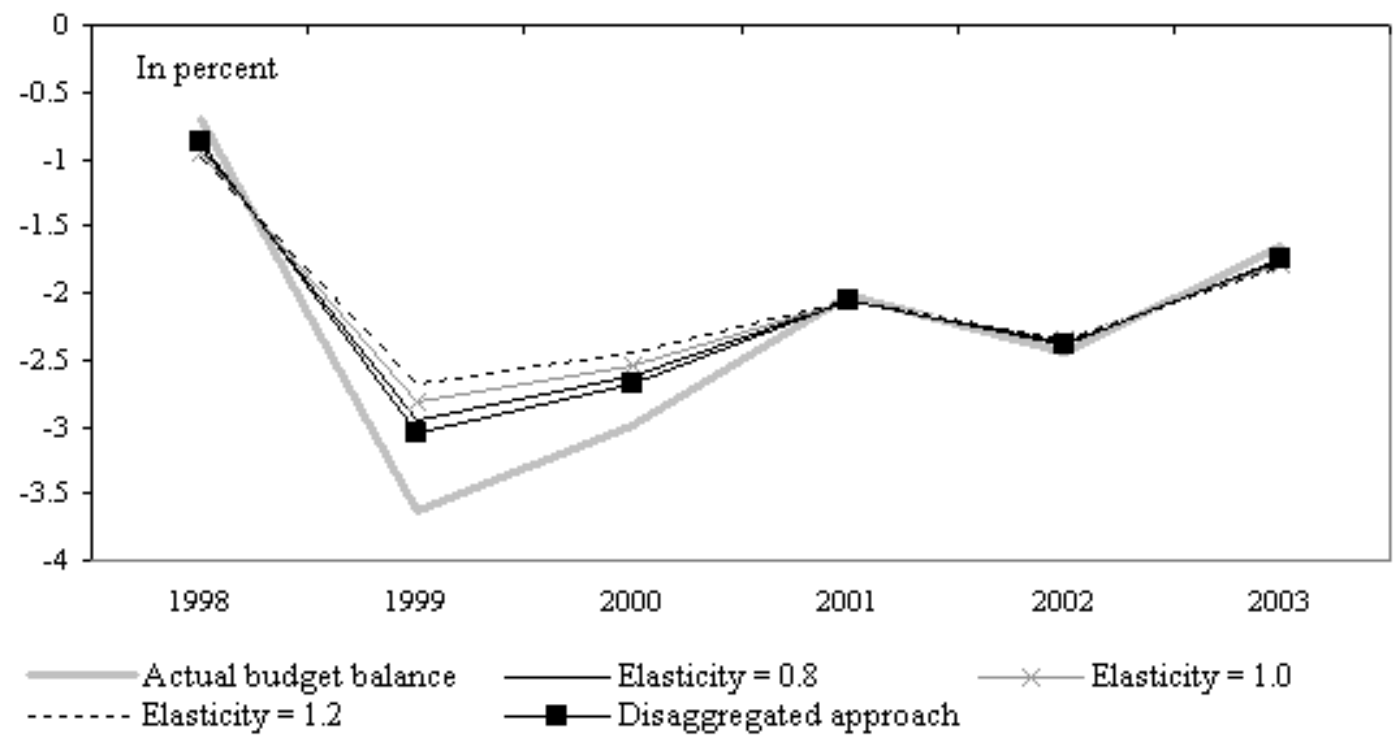


12. As Table IV.1 demonstrates, the structural budget balance gives a clearer picture of the fiscal policy stance in Latvia than can be seen from the actual budget balance. In 1999, the actual fiscal deficit widened from 0.7 percent of GDP to 3.6 percent. Because of the negative impact of the Russia crisis on Latvia output, one would tend to attribute most of the fiscal worsening to this cyclical factor. However, our analysis shows that the cyclical movement in output can only account for one-third of the higher fiscal deficit, while two-thirds of the change in the actual fiscal deficit is due to a discretionary loosening of fiscal policy. In 2000 and 2001, the actual fiscal deficits registered improvements of 0.6 percent of GDP and 1.0 percent of GDP, respectively. Our analysis reveals that about half of the improvement was due to above-trend growth in output, and the magnitude of deliberated fiscal tightening is less than what the actual fiscal deficits suggest.

13. Output was close to potential in 2002 and 2003. For these two years, the changes in the actual budget balance are good indicators of the fiscal stance. Fiscal policy loosened somewhat in 2002, with increases in both the actual and structural budget deficits. In 2003, the actual deficit of 1.6 percent of GDP was much below the 3.2 percent that had been budgeted. The reasons are twofold: unexpectedly high revenues and lower-than-budgeted expenditure and net lending. The analysis of potential output suggests that the GDP assumption in the budget was much lower than the potential level, as the budget only assumed a rate of real growth of 5.5 percent, compared to the actual growth of 7.5 percent. It is worth mentioning that neither the authorities nor the Fund had forecast such high growth. Moving to 2004 and 2005, the fiscal deficits are projected to decline by about 0.2 percent each year, which implies the same changes in the structural fiscal deficits given the estimated output gaps.

\section{Conclusions}

14. The results reported in this chapter give a clearer picture of the fiscal policy stance than can be seen directly from the actual budget balance. In interpreting these results, however, it should be noted that estimating the structural budget balance for transition economies such as Latvia is a challenging task. Any statistical method for purging business cycle influences requires the researcher to observe the behavior of the economic variables over many cycles. But for transition countries, the time span of the data is typically very short and only a few cycles can be observed. Furthermore, because these countries have been experiencing fundamental and continuous changes in the structure of their economies, it is difficult to define and measure the potential output. For example, estimated trend growth excluding 2003 would have been lower. It is still not clear whether the year 2003 signals a permanent rise in the trend output in Latvia. Inevitably, one has to make assumptions. Adding to the problem are ongoing tax reforms and efforts to improve tax collection, which make it impossible to estimate tax elasticities accurately. Therefore the results presented here need to be interpreted with these caveats in mind. However, with additional data and longer time series, future work should improve the accuracy of the calculations and enable the implementation of the production function approach. 


\section{References}

Burgess, Robert, 2001, "Assessing the Stance of Fiscal Policy in Estonia," unpublished, Washington, IMF.

European Policy Committee,2001, Report on Potential Output and the Output Gap, Brussels.

Hagemann, Robert, 1999, “The Structural Budget Balance: The IMF’s Methodology,” IMF Working Paper 99/95, Washington, IMF.

Schmitz, Birgit, 2002, "Potential Output and Cyclically Adjusted Budget Balances for the Baltic Countries," unpublished, Washington, IMF. 